Article

\title{
Stormwater Runoff Characteristics and Effective Management of Nonpoint Source Pollutants from a Highland Agricultural Region in the Lake Soyang Watershed
}

\author{
Jae Heon Cho ${ }^{1, *}$ and Jong Ho Lee ${ }^{2}$ \\ 1 Department of Health and Environment, Catholic Kwandong University, Naegok-Dong, Gangneung-Si, \\ Gangwon-Do 210-701, Korea \\ 2 Department of Urban Planning and Real Estate, Cheongju University, Daeseongro, Sangdang-Gu, Cheongju, \\ Chungbuk 360-764, Korea; jhlee1013@cju.ac.kr \\ * Correspondence: jhcho@cku.ac.kr; Tel.: +82-33-6497534
}

Received: 21 August 2017; Accepted: 3 October 2017; Published: 12 October 2017

\begin{abstract}
The dense highland field area in the upstream region of the Lake Soyang watershed is subject to excessive soil erosion during the wet season. In this study, stormwater runoff from the Lake Soyang watershed was monitored during four rainfall events at 10 locations throughout 2016. The maximum SS concentration at Naedongcheon, which is located in the upper part of the Soyang River, reached $4598 \mathrm{mg} / \mathrm{L}$. The event mean concentration (EMC) of SS loads in Naedongcheon ranged from $82.2 \mathrm{mg} / \mathrm{L}$ to $926.3 \mathrm{mg} / \mathrm{L}$. We found that, although the first flush events were usually concentrated in highly paved urban areas, a first flush occurred in the agricultural area of the dense highland field region. The first flush phenomenon was identified by a dimensionless cumulative runoff mass and volume curve $(M(V)$ curve), and the intensity of the first flush was analyzed by the coefficient of the nonlinear regression model and the $\mathrm{FF}_{30}$ and $\mathrm{FF}_{25}$ values (the fraction of pollution load transported by the first $30 \%$ and $25 \%$ of runoff, respectively). Nonlinear regression models using the power function were applied to fit the $M(V)$ curve, the $\mathrm{FF}_{30}$ values were inversely proportional to the coefficient $a$ of the regression model. A long-term seasonal trend decomposition for monthly turbidity and precipitation was performed for the Lake Soyang. Long-term turbidity trend was approximately coincident with the trend in long-term precipitation. In addition, the present status of the best management practices (BMPs) in the upper part of the Soyang River basin was investigated, and a survey of the management and operation of the BMPs was conducted for selected farmers.
\end{abstract}

Keywords: stormwater runoff monitoring; highland fields; first flush; mass volume curve; nonlinear regression model; seasonal trend decomposition; BMPs

\section{Introduction}

Lake Soyang is located on the upper part of the Han River in South Korea. The human population is concentrated in the lower part of the Han River, including the capital Seoul. Important multiregional water sources are located in this region, and they are used to provide water for areas all over the capital. In the upper part of the Han River, particularly in certain areas of the Yanggu-gun and Hongcheon-gun, highland fields are densely distributed. In general, high soil loss rates occur during intense storms. Moreover, intensive cultivation and socioeconomic pressure for more land have accelerated the rate of soil erosion on sloping lands [1]. During the wet season, the highland fields in this area cause a large amount of suspended sediments to be discharged into the river, which increases the turbidity of Lake Soyang [2]. Phosphorus, which is usually considered the limiting nutrient for primary production, 
is mainly transferred from agricultural soils through runoff and soil erosion [3]. These inputs disrupt the growth of aquatic plants and fish and adversely affect the quality of the water supply [4].

These negative effects were demonstrated in July 2006 during an incident caused by typhoon Ewiniar. A localized and heavy rain occurred in the Lake Soyang watershed. Overall, $670 \mathrm{~mm}$ fell over eight days at a maximum of $66 \mathrm{~mm}$ per hour. Because of the rain, a large amount of suspended sediment from Lake Soyang's watershed entered Lake Soyang. The suspended sediment stayed in Lake Soyang for an extended period because of stratification, thereby increasing the turbidity of the lake, which was measured at over 20 nephelometric turbidity units (NTU) for 168 days. During the flood season, a large amount of nonpoint source pollutants enter Lake Soyang and cause the turbid water phenomena [5].

Because of the rising turbidity of the lake after typhoon Ewiniar, the Ministry of Environment assigned the Lake Soyang watershed area, Yanggu-gun, Hongcheon-gu, and the surrounding areas as a nonpoint source pollution management area. The Ministry committed an extensive budget to enforcing a nonpoint source reduction plan to solve the turbid water phenomenon. Nonpoint source pollutants are difficult to manage, and analyzing the effectiveness of best management practices (BMPs) is also difficult [6-8]. Feedback from planned and regular monitoring and a quantitative assessment is essential. From a short-term monitoring perspective, it is challenging to analyze the effectiveness of BMPs for a variety of precipitation and runoff characteristics. Therefore, long-term monitoring, such as measurements of runoff quality and quantity, and analyses of the effects of BMPs are necessary [9].

To manage suspended sediment-related water quality issues in fluvial systems, sediment transport must be accurately quantified at the desired river locations [10]. However, continuous monitoring systems have not been installed in the Soyang River to obtain suspended sediment data. Runoff quality and flow depends greatly on rainfall characteristics, such as the rainfall depth, rainfall duration period, number of preceding dry days and catchment topography. In addition, stormwater runoff depends upon the land use pattern of the basin $[3,11]$. In this study, stormwater runoff was monitored and characterized by considering the diverse catchment characteristics and the present condition of the BMPs implemented in the study area was analyzed.

The water quality characteristics of each rainfall event were evaluated via storm water flow and water quality measurements at 10 targeted points in the nonpoint source pollution management area. During a storm event, a first flush phenomenon occurs wherein most of the pollution load is transported in the initial part of the discharge volume [12-14]. In many cases, the half inch rule was applied to treat urban runoff pollutants. Essentially, the rule states that $90 \%$ of an event's total pollutant load is transported in the first half inch of runoff [15]. By analyzing the pollutographs, hydrographs, and dimensionless mass and volume $(M(V))$ curves of each storm event $[12,16,17]$ and applying regression models, this study assessed whether the first flush phenomenon occurs in the study area [14,18-20]. The intensity of the first flush was analyzed by the coefficient of the nonlinear regression model using a power function and the $\mathrm{FF}_{30}$ and $\mathrm{FF}_{25}$ values (the fraction of pollution load transported by the first $30 \%$ and $25 \%$ of runoff, respectively) [21-23].

The characteristics of the pollution loads, the event mean concentration (EMC) $[13,24,25]$, and the pollution loads per unit area were analyzed. Analyses were also performed to determine the management condition of the BMPs. This study investigated BMP management and operations and focused on the resident farmers within the nonpoint source pollution management area to evaluate their opinions. By exploring and analyzing the various research results from the nonpoint source pollution management area, effective alternatives for reducing sediment discharge in the Lake Soyang watershed area can be assessed. 


\section{Materials and Methods}

\subsection{Study Area and Rainfall Characteristics of the Stormwater Survey Area}

Lake Soyang is the largest freshwater lake in South Korea, and most of the watershed consists of forested terrain. Accordingly, the population density in the area is low. Lake Soyang watershed's nonpoint source pollution management area was re-assigned by the Ministry of Environment on 15 October 2015. The nonpoint source pollution management area includes the Mandae area and the Gaah area of the Inbukcheon watershed and the Jaun area of the Naerincheon watershed. The management area consists of dense highland fields. During the wet season, these fields cause a large amount of suspended sediment to be discharged into local streams and Lake Soyang, which increases the turbidity.

The Soyang River basin and sampling stations are shown in Figure 1. The present land use and areas of the studied sub-basins are presented in Table 1. Among the Lake Soyang management area sub-basins, the Mandaecheon sub-basin has the highest proportion of agricultural land at 27.7\%. Most of the agricultural land consists of highland dry fields. The Mandae area is adjacent to the South and North Korea border. The Jungjohangcheon sub-basin has the highest sediment yields within the Jaun area and is composed of $14.6 \%$ agricultural land and $84.1 \%$ forest land. Generally, the percentage of highland field areas is greater than the percentage of paddy field areas.

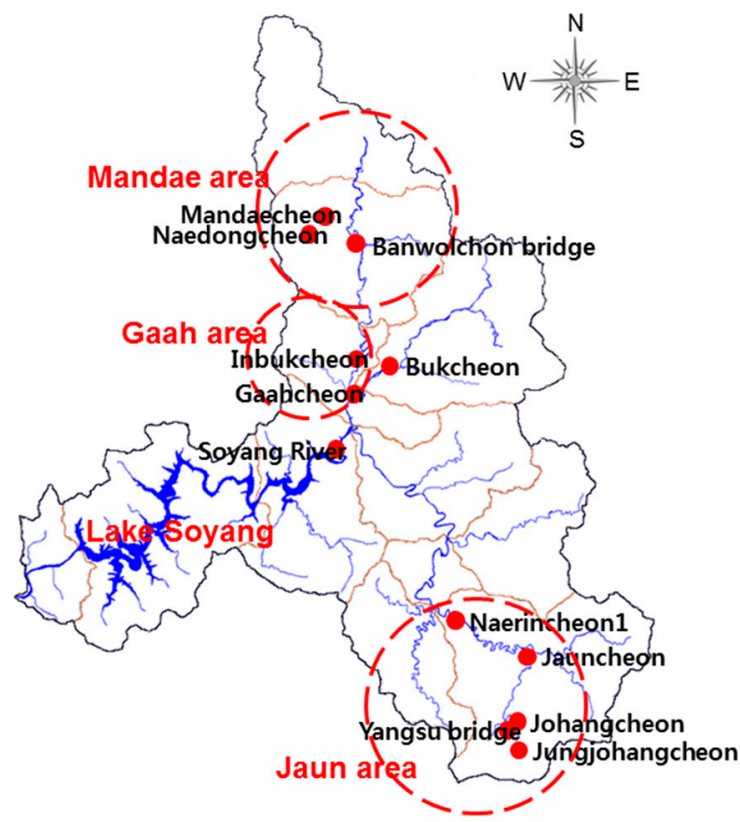

Figure 1. Soyang River basin and stormwater survey stations.

Table 1. Land use of the streams at Lake Soyang.

\begin{tabular}{ccccccc}
\hline \multirow{2}{*}{ Stream } & \multirow{2}{*}{$\begin{array}{c}\text { Sub-Basin } \\
\text { Area (ha) }\end{array}$} & Forest (ha) & $\begin{array}{c}\text { Upland } \\
\text { Field (ha) }\end{array}$ & $\begin{array}{c}\text { Paddy } \\
\text { Field (ha) }\end{array}$ & Others (ha) & $\begin{array}{c}\text { Proportion of } \\
\text { Agricultural Land (\%) }\end{array}$ \\
\cline { 3 - 7 } & & 860 & 150 & 0 & 12 & 14.6 \\
Jungjohangcheon & 1022 & 3556 & 489 & 0.3 & 117 & 12.0 \\
Johangcheon & 4161 & 11,703 & 1445 & 0.4 & 493 & 11.0 \\
Jauncheon & 13,641 & 37,391 & 1942 & 0.4 & 1014 & 5.0 \\
Naerincheon 1 & 40,347 & 1261 & 1261 & 420 & 3137 & 27.7 \\
Mandaecheon & 6079 & 20,792 & 3373 & 2384 & 23,349 & 11.5 \\
Inbukcheon & 49,898 & 12,910 & 2582 & 922 & 12,403 & 12.2 \\
Bukcheon & 28,817 & 1104 & 578 & 298 & 2752 & 18.5 \\
Gaahcheon & 4732 & 78,664 & 20,828 & 9760 & 89,951 & 15.4 \\
Soyang River & 199,203 & & & & & \\
\hline
\end{tabular}


This study selected the Inje weather station as the collection point for the rainfall data of the Mandae and Gaah area. Changchon's rainfall gauging station was used as the collection point for the rainfall data of the Jaun area. During early and mid-July 2016, heavy rainfall occurred. At the Inje weather station and Changchon rainfall gauging station, the rainfall depths in July were $546 \mathrm{~mm}$ and $457 \mathrm{~mm}$, respectively. The monthly rainfall data from the Inje weather station over the past six years is listed in Table 2. The average recorded rainfall levels in 2013, 2014, and 2015 were well below the typical level. In 2016, the rainfall was heavier than in 2014 and 2015. As a reference, the regular annual rainfall in the Inje area over 30 years was $1210.6 \mathrm{~mm}$. Variance in rainfall has an effect on the turbidity of the Soyang River watershed. For the rainfall events, the rainfall depth, rainfall duration period, number of preceding dry days, and rainfall depths of the prior five days are shown in Table 3.

Table 2. Monthly rainfall depth at the Inje weather station.

\begin{tabular}{|c|c|c|c|c|c|c|c|c|c|c|c|c|c|c|}
\hline Year & January & February & March & April & May & June & July & August & September & October & November & December & $\begin{array}{l}\text { Annual Total } \\
(\mathrm{mm})\end{array}$ & $\begin{array}{c}\text { National } \\
\text { Average (mm) }\end{array}$ \\
\hline 2012 & 4.6 & 0.5 & 27.6 & 122 & 21 & 71 & 230 & 261 & 126 & 60.6 & 53.0 & 43.7 & 1023 & 1479 \\
\hline 2013 & 13.9 & 40.2 & 43.2 & 57 & 74 & 96 & 633 & 141 & 139 & 17.0 & 48.3 & 25.8 & 1332 & 1163 \\
\hline 2015 & 10.6 & 18.2 & 12.1 & 80 & 23 & 43 & 236 & 118 & 27 & 52.5 & 113.1 & 18.6 & 755 & 948 \\
\hline 2016 & 0.3 & 41.3 & 41.3 & 93 & 88 & 51 & 546.5 & 96 & 46.3 & 107.1 & 16.0 & 57.6 & 1184 & 1272 \\
\hline
\end{tabular}

Table 3. Stormwater runoff monitoring for rainfall events in the Lake Soyang watershed in 2016.

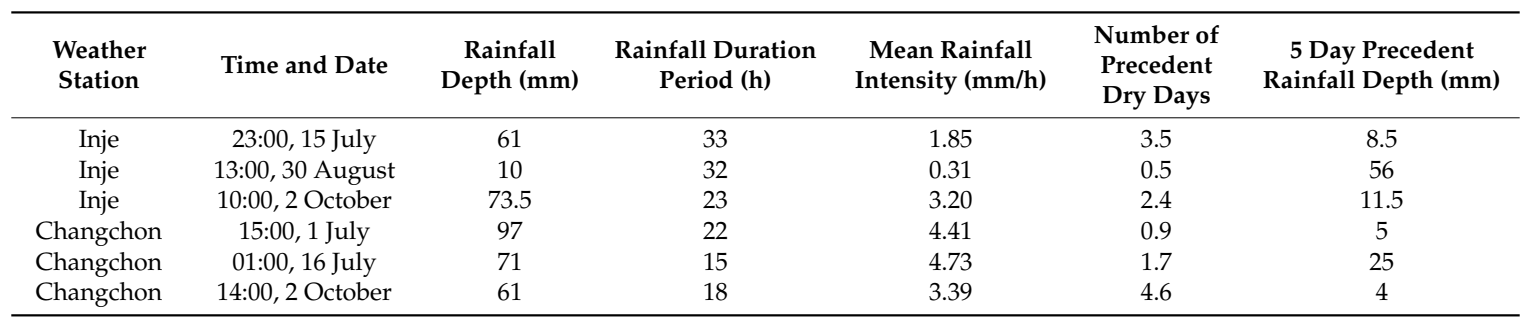

\subsection{Stormwater Runoff Survey}

To monitor the nonpoint source pollution management of the Lake Soyang watershed, 10 points were selected to monitor the storm water runoff from the Jaun area, the Mandae area, and the Gaah area. From the Mandae and Gaah area, six points were selected in Naedongcheon, Mandaecheon, Inbukcheon, Gaahcheon, Bukcheon, and the Soyang River. Among these points, the Naedongcheon, Mandaecheon and Gaahcheon sub-basins consist of dense highland fields, and Naedongcheon and Mandaecheon points are located on the upper part of the Inbukcheon. Bukcheon and Inbukcheon are tributaries of the Soyang River. Additionally, from the Jaun area, four points were selected in Jungjohangcheon, Johangcheon, Jauncheon, and Naerincheon 1. In the Jungjohangcheon and Johangcheon sub-basins, highland fields are densely distributed. Jauncheon and Naerincheon 1 points are upstream of the Soyang River. From September's stormwater runoff survey, Banwolchon Bridge was examined instead of the Inbukcheon point, and Yangsu Bridge was examined instead of the Johangcheon point. The locations of the monitoring points are shown in Figure 1.

During rainfall, water sampling and flow measurements were performed at the same time. The cross sections of the research area were surveyed before the rainfall events. Field surveys were conducted to perform flow measurements at most of the survey points. For the remaining points, such as the Inbukcheon, Bukcheon, Soyang River, and Naerincheon 1 points, real-time water level and flow measurements were obtained from the Ministry of Land Infrastructure and Transport and the Korea Water Resources Corporation. The sampled water from the measurement sites was delivered to the laboratory as quickly as possible, and biochemical oxygen demand (BOD), chemical oxygen demand (COD), suspended sediments (SS), total phosphorus (TP), total nitrogen (TN), and total organic carbon (TOC) were analyzed using standard methods. 


\section{3. $M(V)$ Curve and a Nonlinear Regression Model Using the Power Function and the Third-Degree Polynomial Function}

The dimensionless cumulative runoff flow ratio $(V)$ of certain rainfall events is calculated as the ratio of the cumulative runoff flow to the total runoff flow volume. The dimensionless cumulative pollution load ratio $(M)$ is calculated as the ratio of the cumulative pollution load to the total pollution load. Using the flow $\left(Q_{i}\right)$ at $N$ number of time steps $(\Delta t)$ and the concentration $\left(C_{i}\right)$ of a water quality parameter measurement data, the cumulative runoff flow ratio and the cumulative pollution load ratio of the $M(V)$ curve are calculated as shown in the following equation [12]:

$$
M(V)=\frac{\sum_{i=1}^{j} C_{i} Q_{i} \Delta t_{i}}{\sum_{i=1}^{N} C_{i} Q_{i} \Delta t_{i}}=f\left[\frac{\sum_{i=1}^{j} Q_{i} \Delta t_{i}}{\sum_{i=1}^{N} Q_{i} \Delta t_{i}}\right]=f\left[\frac{\sum_{i=1}^{j} \Delta V_{i}}{\sum_{i=1}^{N} \Delta V_{i}}\right]=f(V)
$$

where $N$ represents the number of total measurement data and $\Delta V_{i}$ represents the runoff flow volume during the time step $\Delta t_{i}$. Through the above calculation, a $M(V)$ curve can be developed. The $M(V)$ curve shows the runoff characteristics of each rainfall event. For a uniform runoff water quality $\left(C_{i}\right.$ is constant) throughout the rainfall event, the $M(V)$ curve will pass through the origin and become a straight line with a slope equal to 1, i.e., 1:1 line [16].

Dimensionless $M(V)$ curves can be fitted by a power function $[12,20,26]$ and a third-degree polynomial function $[23,26]$ :

$$
\begin{gathered}
M(V)=V^{a} \\
M(V)=b V^{3}+c V^{2}+d V
\end{gathered}
$$

where coefficient $a, b, c, d$ were derived from the nonlinear regression models. The value of coefficient $a$ characterizes the gap between the $M(V)$ curve and the bisector in the $M(V)$ diagram. Coefficient $a$ of the power function also represents the intensity of the first flush. In $M(V)$ curve fitting, the power function and third-degree polynomial function are compared via the performance of the regression model. The XLSTAT data analysis solution [27] was used to conduct the nonlinear regression.

\subsection{EMC}

Water quality parameters exhibit large variations throughout each runoff event. In addition, the concentration in the receiving body of water represents a response to the total load rather than to the concentration variability within each particular event [28]. The EMC was defined as the pollutant mass contained in the runoff event divided by the total flow volume of the event.

$$
\mathrm{EMC}=\frac{\sum Q_{i} C_{i} \Delta t}{\sum Q_{i} \Delta t}
$$

The EMC is often used to estimate stormwater pollutant loads $[25,29]$ and investigates the occurrence of a seasonal first flush [13]. Grum et al. [24] analyzed the underlying structure of systematic variations in the EMCs of pollutants in combined sewers during rainfall events. We calculated the EMC and pollutant loads per unit area at each sub-basin to characterize the stormwater runoff in the study area.

\subsection{Investigation of the BMPs Implemented in the Study Area}

Within the nonpoint source pollution management area of Lake Soyang, 102 BMPs are in place in the Haean-myun area of Yanggu-gun, 35 are in place in the Gaahrri area of Inje-gun, and 101 are in place in the Jaun-ri area of Hongcheon-gun. In the Mandae area of Yanggu-gun, a BMP project $[28,30]$ was implemented in 2016, which included tasks such as building settling basins, gabion walls, and slope protection works. From 2008 to 2013, a fruit cultivation conversion project that supported 172 farms was implemented. In the Gaah area of Injae-gun, settling basins, slope protection works, and concrete channel facilities were also installed; moreover, the previous multistage 
sedimentation basin building plan was changed to the muddy water reduction plan for pollution sources. The Jaun area of Hongcheon-gun built multistage sedimentation basins, slope protection works, and gabion walls. In addition, this area is currently in the process of constructing another multistage sedimentation basin as well as gabion walls and restoring the cutting area.

The locations of 102 facilities for BMPs in the Mandae area of Yanggu-gun are shown in Figure 2, and photographs of several BMPs installed in the Lake Soyang watershed area are presented in Figure 3. In this study, a survey was conducted to assess the operations and management of BMPs by targeting farmers in the Mandae, Gaah, and Jaun areas, which have frequent problems with turbid water.

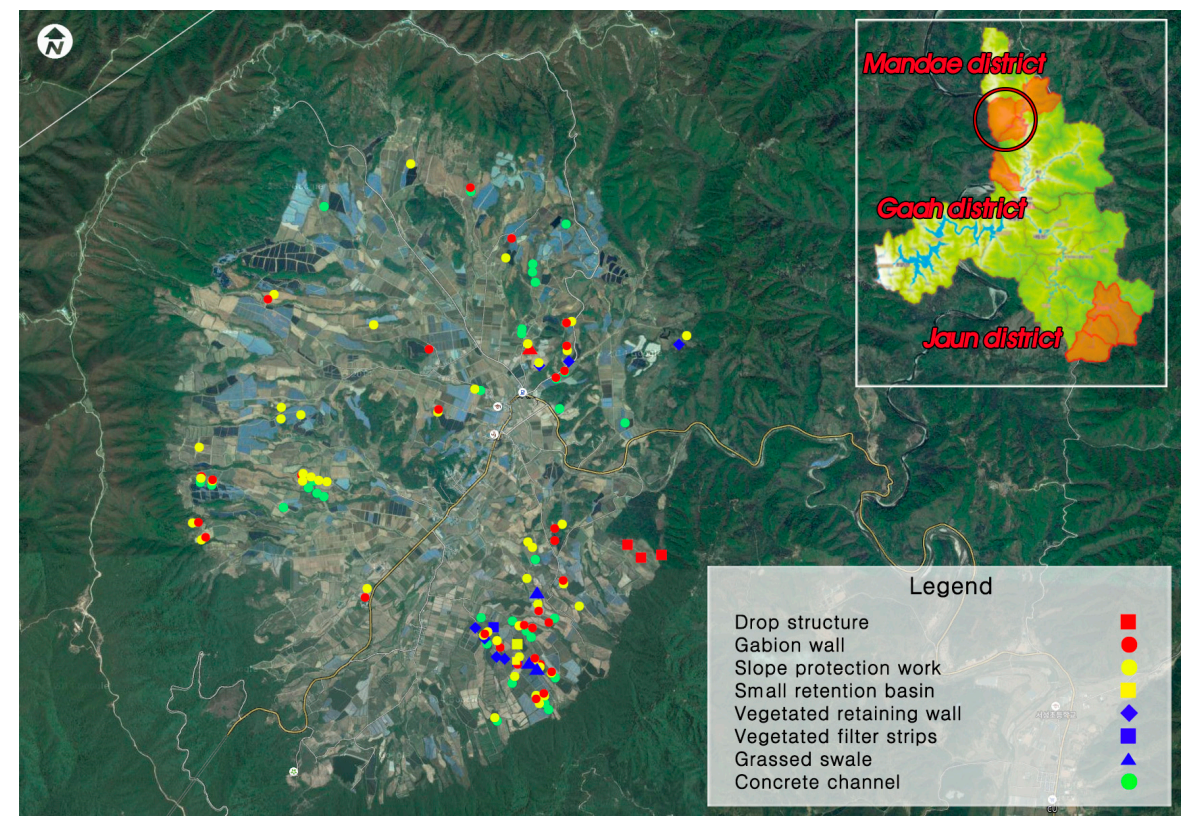

Figure 2. Map of the BMPs in the Madae area of Yanggu-gun.

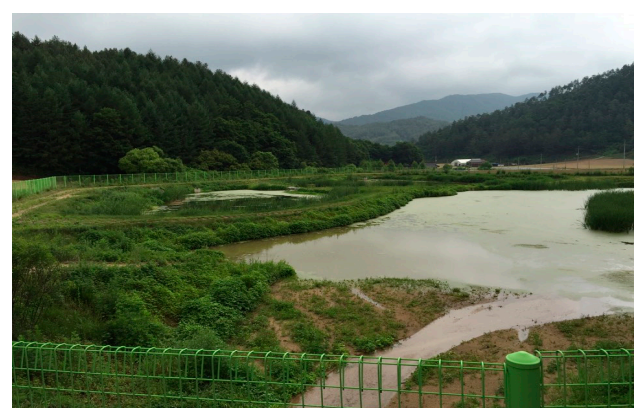

(a)

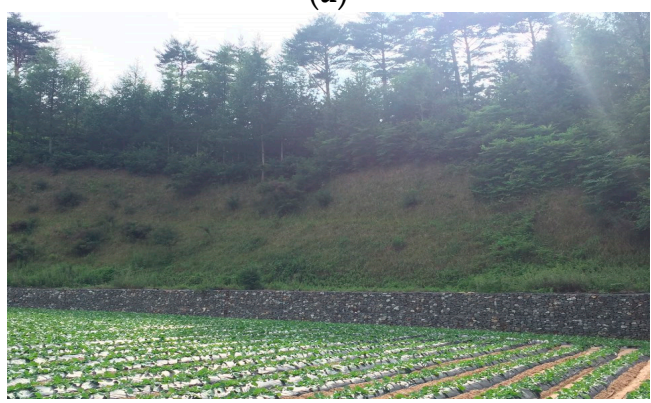

(c)

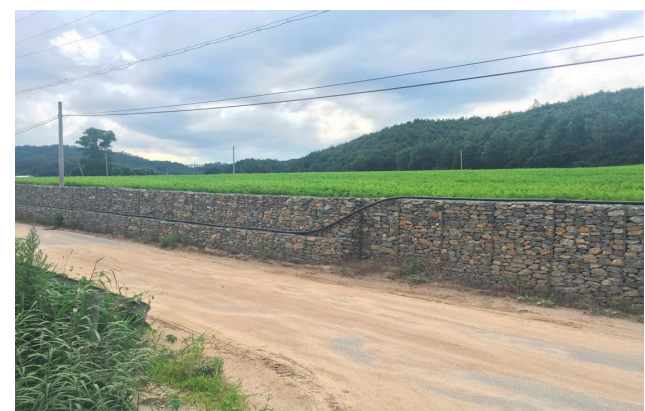

(b)

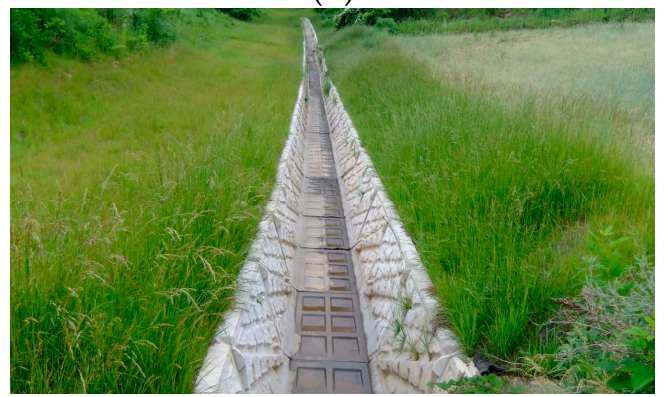

(d)

Figure 3. Cont. 


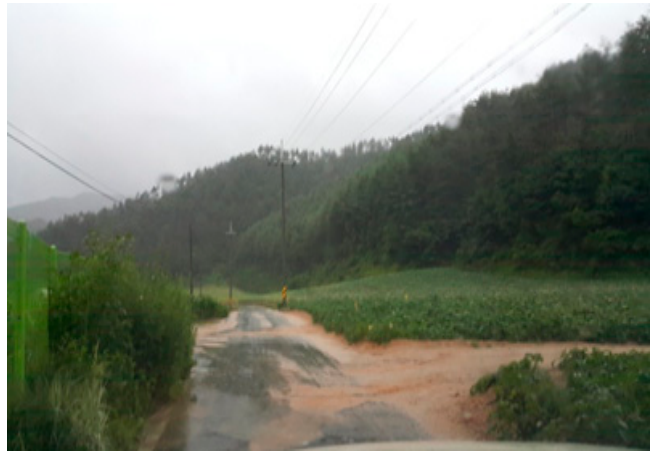

(e)

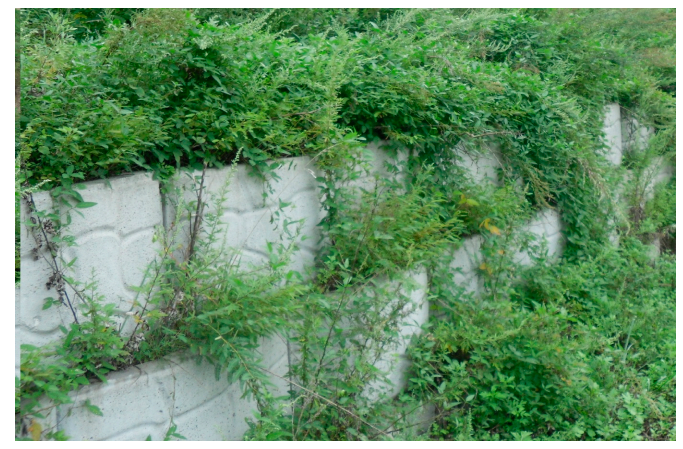

(f)

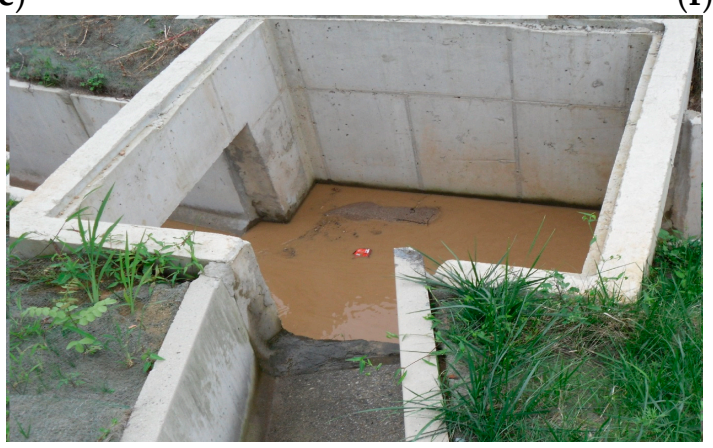

(g)

Figure 3. BMPs in the Lake Soyang basin: (a) multistage sedimentation basin; (b) gabion wall; (c) slope protection work; (d) concrete channel; (e) current situation of sediment runoff on the roadside in the Jaun area on 18 July 2016; (f) vegetated retaining wall; and (g) drop structure.

\section{Results and Discussion}

\subsection{Characteristics of Water Quality and Pollutant Runoff in Sub-Watersheds}

\subsubsection{Runoff Water Quality}

The stormwater runoff survey was conducted three times at each of the survey points. In Jungjohangcheon and Johangcheon, which are in the upper part of the Jaun area, dense areas of highland fields are observed. These areas were identified as having a large range of fluctuations in nutrients, such as SS, TP and TN. Variations in the SS loads and water quality decreased as the flow was transported to the lower areas, including Jauncheon and Naerincheon 1. In Naedongcheon, which is in the upper part of the Mandae area, variations in the SS content and water quality were large and the mean values of the water quality measurements were high.

From the Naedongcheon to the Inbukcheon, the range of fluctuations in the SS content and water quality decreased, as indicated by standard deviation values in Table 4. As shown in Table 4, the maximum SS concentration of Jungjohangcheon is $1152 \mathrm{mg} / \mathrm{L}$ and the maximum SS concentration of Naedongcheon reached $4598 \mathrm{mg} / \mathrm{L}$. Limited variations in the water quality of Bukcheon are observed, and the mean value of the water quality measurements is also low. The turbidity and water quality concentration in Gaahcheon is low compared with that in areas with dense highland fields, such as Naedongcheon and Jungjohangcheon. The Soyang River is the furthest downstream and shows a smaller mean water quality value and fewer variations than the areas with dense highland fields, although the average SS and variations in SS content are greater than those of Bukcheon and Gaahcheon. 
Table 4. Stormwater runoff water quality in the Lake Soyang watershed.

\begin{tabular}{|c|c|c|c|c|c|c|c|}
\hline \multicolumn{2}{|c|}{ Survey Points } & $\begin{array}{c}\text { SS } \\
(\mathrm{mg} / \mathrm{L})\end{array}$ & $\begin{array}{c}\text { COD } \\
(\mathrm{mg} / \mathrm{L})\end{array}$ & $\begin{array}{c}\text { BOD } \\
(\mathrm{mg} / \mathrm{L})\end{array}$ & $\begin{array}{c}\text { TN } \\
(\mathrm{mg} / \mathrm{L})\end{array}$ & $\begin{array}{c}\text { TP } \\
(\mathrm{mg} / \mathrm{L})\end{array}$ & $\begin{array}{c}\text { TOC } \\
(\mathrm{mg} / \mathrm{L})\end{array}$ \\
\hline \multirow{5}{*}{ Jungjohangcheon } & Max. & 1152 & 35.0 & 4.8 & 12.910 & 2.488 & 6.1 \\
\hline & Min. & 0.5 & 2.6 & 0.1 & 4.240 & 0.024 & 0.8 \\
\hline & Median & 29.8 & 8.4 & 0.9 & 8.210 & 0.168 & 2.5 \\
\hline & Mean & 133 & 10.4 & 1.3 & 8.430 & 0.410 & 2.8 \\
\hline & Standard deviation & 258 & 8.2 & 1.1 & 2.56 & 0.579 & 1.60 \\
\hline \multirow{5}{*}{ Johangcheon } & Max. & 1084 & 102.0 & 11.5 & 15.220 & 4.535 & 7.8 \\
\hline & Min. & 1.0 & 4.6 & 0.3 & 5.330 & 0.054 & 1.7 \\
\hline & Median & 28.5 & 8.6 & 1.3 & 7.300 & 0.119 & 3.9 \\
\hline & Mean & 170 & 22.0 & 2.6 & 8.670 & 0.683 & 4.1 \\
\hline & Standard deviation & 301 & 29.6 & 3.0 & 3.18 & 1.207 & 2.00 \\
\hline \multirow{5}{*}{ Jauncheon } & Max. & 680 & 40.8 & 6.6 & 10.440 & 1.656 & 6.8 \\
\hline & Min. & 0.8 & 4.0 & 0.4 & 4.080 & 0.023 & 1.4 \\
\hline & Median & 38.0 & 7.6 & 1.0 & 8.190 & 0.158 & 2.1 \\
\hline & Mean & 100 & 11.3 & 1.7 & 7.580 & 0.331 & 2.9 \\
\hline & Standard deviation & 169.7 & 8.9 & 1.6 & 1.71 & 0.437 & 1.52 \\
\hline \multirow{5}{*}{ Naerincheon 1} & Max. & 50.0 & 8.8 & 1.6 & 6.370 & 0.131 & 7.0 \\
\hline & Min. & 1.2 & 3.0 & 0.2 & 1.650 & 0.014 & 0.5 \\
\hline & Median & 7.2 & 4.4 & 0.5 & 3.070 & 0.028 & 0.9 \\
\hline & Mean & 14.9 & 5.1 & 0.6 & 3.030 & 0.050 & 2.5 \\
\hline & Standard deviation & 15.0 & 2.1 & 0.5 & 0.83 & 0.040 & 2.55 \\
\hline \multirow{5}{*}{ Naedongcheon } & Max. & 4598 & 110.0 & 13.6 & 19.070 & 6.024 & 6.6 \\
\hline & Min. & 3.0 & 2.2 & 0.1 & 2.510 & 0.035 & 0.8 \\
\hline & Median & 94.7 & 7.1 & 0.8 & 4.230 & 0.321 & 2.3 \\
\hline & Mean & 463.5 & 17.0 & 2.0 & 5.110 & 0.785 & 2.6 \\
\hline & Standard deviation & 920.0 & 27.4 & 3.4 & 3.39 & 1.512 & 1.20 \\
\hline \multirow{5}{*}{ Mandaecheon } & Max. & 1488 & 44.8 & 7.6 & 7.490 & 2.393 & 8.0 \\
\hline & Min. & 25.5 & 2.4 & 0.1 & 1.950 & 0.048 & 1.1 \\
\hline & Median & 109 & 7.8 & 0.9 & 3.520 & 0.214 & 2.6 \\
\hline & Mean & 266 & 12.3 & 1.5 & 3.880 & 0.463 & 2.9 \\
\hline & Standard deviation & 375.9 & 12.3 & 2.0 & 1.27 & 0.599 & 1.45 \\
\hline \multirow{5}{*}{ Inbukcheon } & Max. & 107.0 & 8.4 & 1.0 & 2.510 & 0.168 & 4.2 \\
\hline & Min. & 2.2 & 3.8 & 0.1 & 0.920 & 0.010 & 2.2 \\
\hline & Median & 14.0 & 5.4 & 0.5 & 1.180 & 0.026 & 2.7 \\
\hline & Mean & 19.0 & 5.4 & 0.5 & 1.350 & 0.037 & 3.0 \\
\hline & Standard deviation & 23.7 & 1.4 & 0.3 & 0.45 & 0.037 & 0.72 \\
\hline \multirow{5}{*}{ Bukcheon } & Max. & 45.5 & 12.2 & 1.2 & 2.240 & 0.049 & 2.6 \\
\hline & Min. & 0.8 & 3.8 & 0.1 & 0.630 & 0.001 & 0.6 \\
\hline & Median & 2.5 & 5.1 & 0.4 & 0.990 & 0.010 & 1.9 \\
\hline & Mean & 6.6 & 5.8 & 0.4 & 1.080 & 0.015 & 1.7 \\
\hline & Standard deviation & 10.3 & 2.2 & 0.2 & 0.41 & 0.013 & 0.70 \\
\hline \multirow{5}{*}{ Gaahcheon } & Max. & 18.4 & 5.5 & 0.6 & 2.030 & 0.045 & 2.0 \\
\hline & Min. & 1.6 & 3.4 & 0.2 & 0.950 & 0.001 & 0.7 \\
\hline & Median & 5.6 & 5.2 & 0.5 & 2.080 & 0.026 & 2.1 \\
\hline & Mean & 18.4 & 5.5 & 0.6 & 2.030 & 0.045 & 2.0 \\
\hline & Standard deviation & 36.4 & 1.6 & 0.3 & 0.65 & 0.061 & 0.83 \\
\hline \multirow{5}{*}{ Soyang River } & Max. & 296 & 18.4 & 1.9 & 2.310 & 0.377 & 5.3 \\
\hline & Min. & 1.6 & 2.0 & 0.1 & 0.800 & 0.003 & 0.2 \\
\hline & Median & 5.0 & 4.5 & 0.3 & 1.260 & 0.013 & 2.3 \\
\hline & Mean & 25.3 & 5.5 & 0.6 & 1.410 & 0.040 & 2.4 \\
\hline & Standard deviation & 67.6 & 3.8 & 0.6 & 0.40 & 0.078 & 1.39 \\
\hline
\end{tabular}

Typical pollutographs at most of the upstream survey points (Naedongcheon) in the Mandae area are shown in Figure 4. Weather data for 16-17 July showed that the rainfall depth was $61 \mathrm{~mm}$, the rainfall duration period was $33 \mathrm{~h}$, and the number of preceding dry days was 3.5. The peak flow and water quality, such as the SS, TP, BOD, and TOC concentrations, were recorded the same time. The variable patterns in SS concentrations and flow indicate that a first flush phenomenon occurred for this rainfall event. 

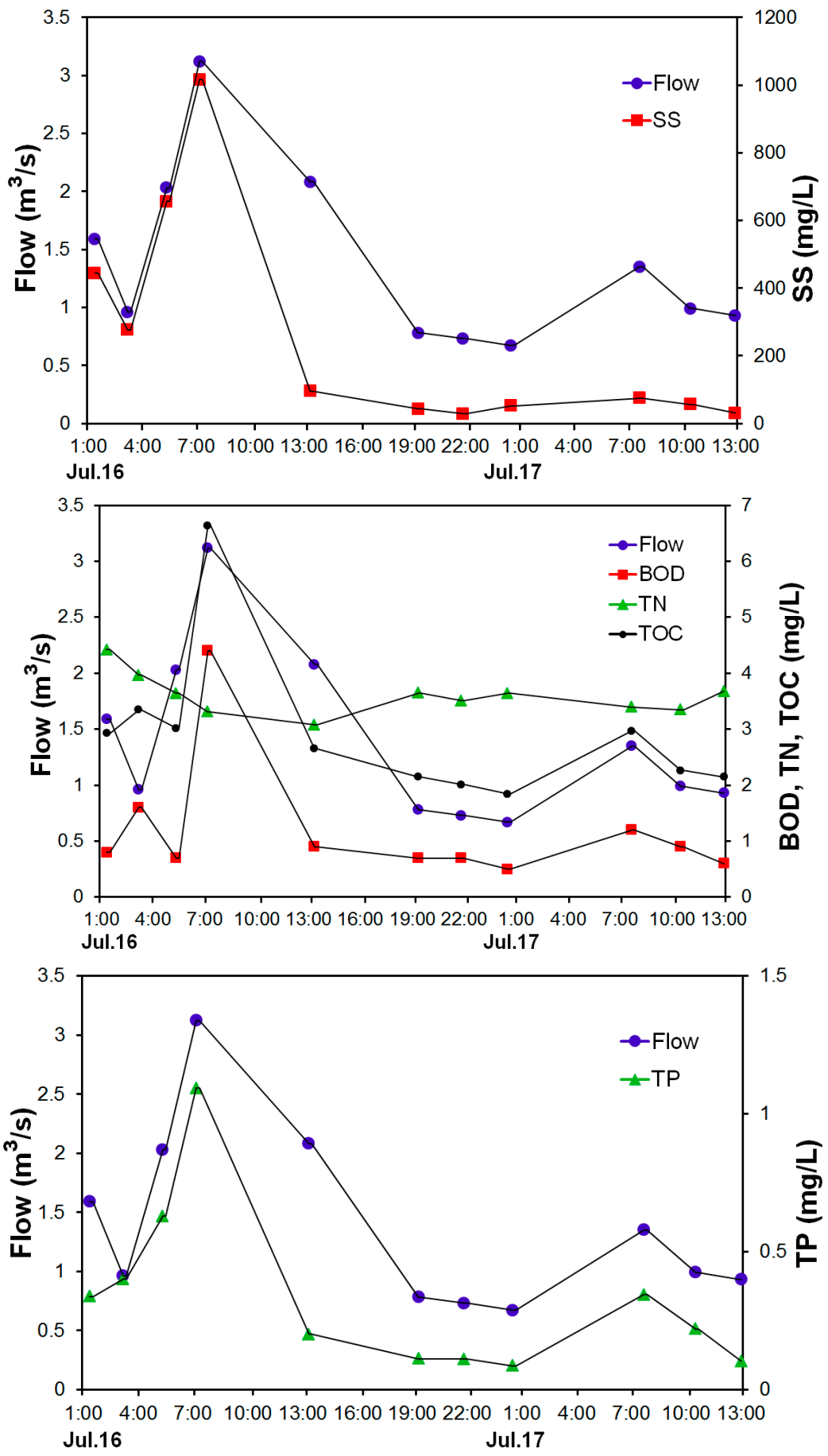

Figure 4. Variation of stormwater runoff water quality and flow at Naedongcheon (16 and 17 July 2016).

\subsection{2. $\mathrm{M}(\mathrm{V})$ Curve Fitting and First Flush}

When drawing the mass-volume curve for each rainfall event, most of the measurement values are placed above the $45^{\circ}$ straight line. If the points are significantly higher above this $45^{\circ}$ straight line, then large quantity of the pollution load is discharged in the initial stage of rainfall and the runoff pollution load continuously declines over time. This type of runoff pattern could be indicative of a first flush. However, most of the measurement data points are distributed below the $45^{\circ}$ straight line, which indicates that a large quantity of the pollution load was discharged at the final stage of rainfall. 
As indicated by the $M(V)$ curve, the first flush effect in Naedongcheon is easily observed because many of the observed values from 16 July to 17 July and from 2 October to 3 October were marked above the straight line at a slope of 1 (Figure 5). Based on the storm water survey from 1 July to 2 July 2017, the $M(V)$ curves of the SS and TP from Jungjohangcheon were drawn and indicate a first flush based on the number of data points falling above the straight line at a slope of 1 (Figure 6). In Naedongcheon (the upper part of the Mandae area) and Jungjohangcheon (the upper part of the Jaun area), the first flush is indicated by the SS, TP and BOD values. Although the first flush mostly occurs during storm events in highly paved watersheds in urban and mixed land use areas $[14,17,23]$, the first flush phenomenon was identified in the agricultural region of this study, where excessive soil erosion occurs. The shape of the $M(V)$ curve of the rainfall event occurring on 1-3 October in Jungjohangcheon is concave (Figure 6) because the rainfall intensity was high at the final stage of rainfall.
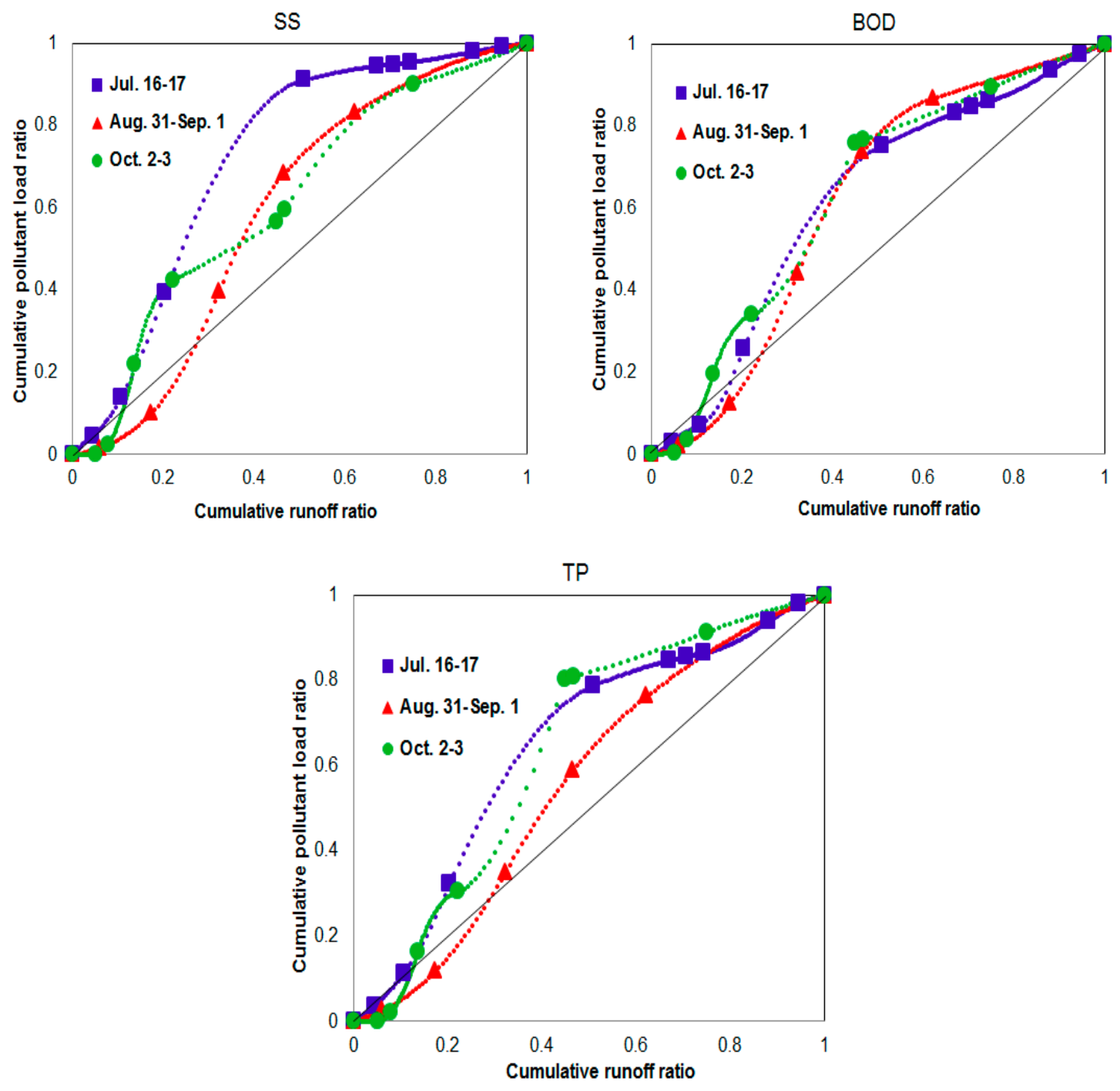

Figure 5. $M(V)$ curve for Naedongcheon. 

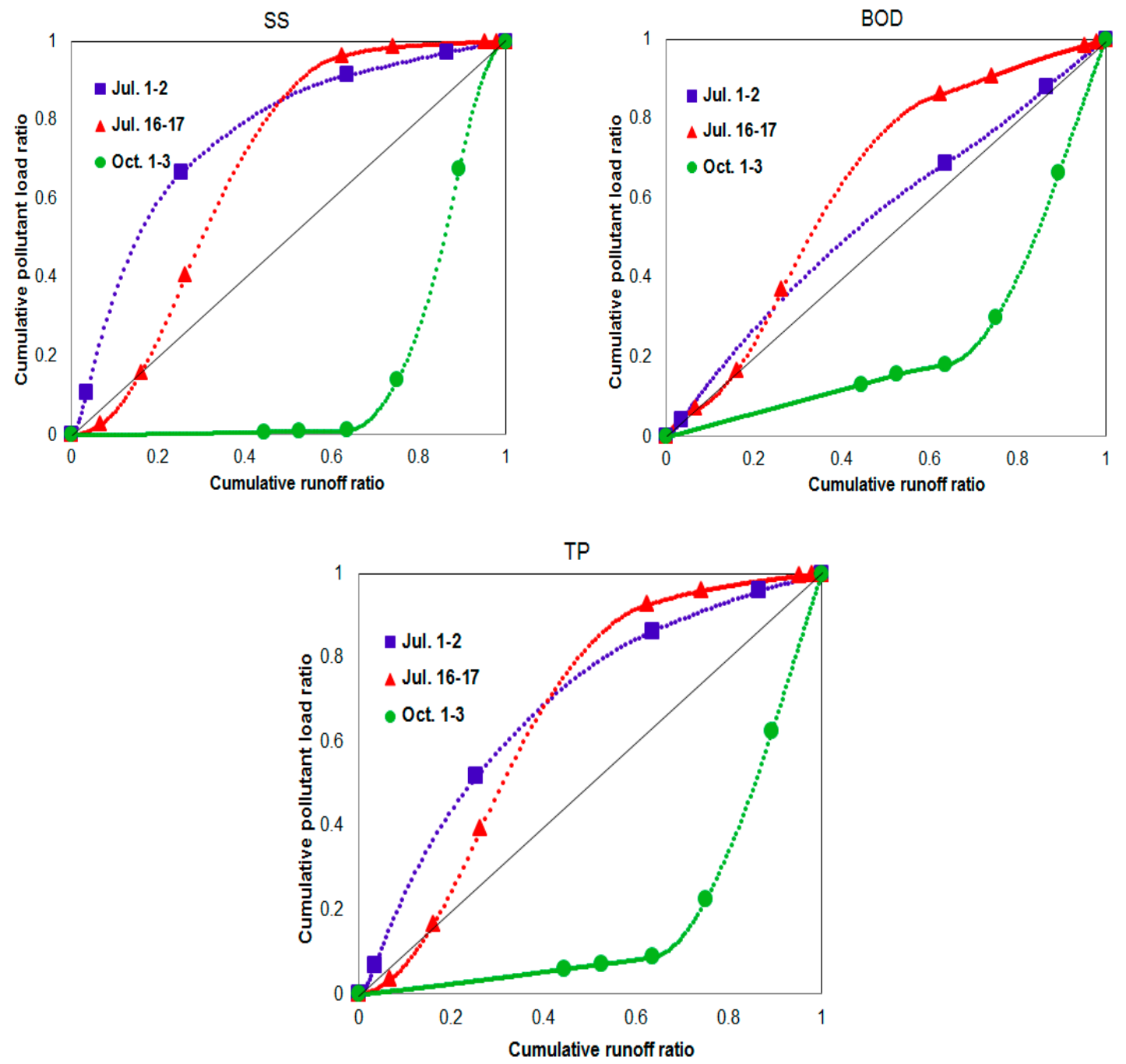

Figure 6. $M(V)$ curve for Jungjohangcheon.

One of the advantages of using the function formula is that the occurrence and degree of the first flush can be easily detected and characterized by the function coefficients, which can be used to compare the results of different studies to obtain a general understanding of the phenomenon [23]. When the nonlinear regression models using the power function (Figures 7-11) and third-degree polynomial function (Figure 12) are compared, the performance of the third-degree polynomial function is slightly better than that of the power function, as shown in Table 5. The performance of the regression model was evaluated using the coefficient of determination $\left(R^{2}\right)$ and the root mean square error (RMSE). For the power function, the $R^{2}$ of $16-17$ July at Naedongcheon ranged from 0.943 to 0.973 , and for the third-degree polynomial function, the $R^{2}$ values ranged from 0.988 to 0.991 . The RMSE values of the third-degree polynomial function (0.045-0.052) are lower than those of the power function (0.079-0.125).

Figure 12 presents the $M(V)$ curve fitting using a third-degree polynomial function. The cumulative pollutant load ratio should increase to 1.0 until the cumulative runoff volume ratio reaches 1.0. However, the last section of the mass-volume data of Figure 12 shows that the value of the cumulative pollutant load ratio decreases. In the case of $M(V)$ curve fitting using the power function, the cumulative pollutant load ratio gradually increases and a limited difference is observed in the performance of the regression model compared with the third-degree polynomial function. 
SS
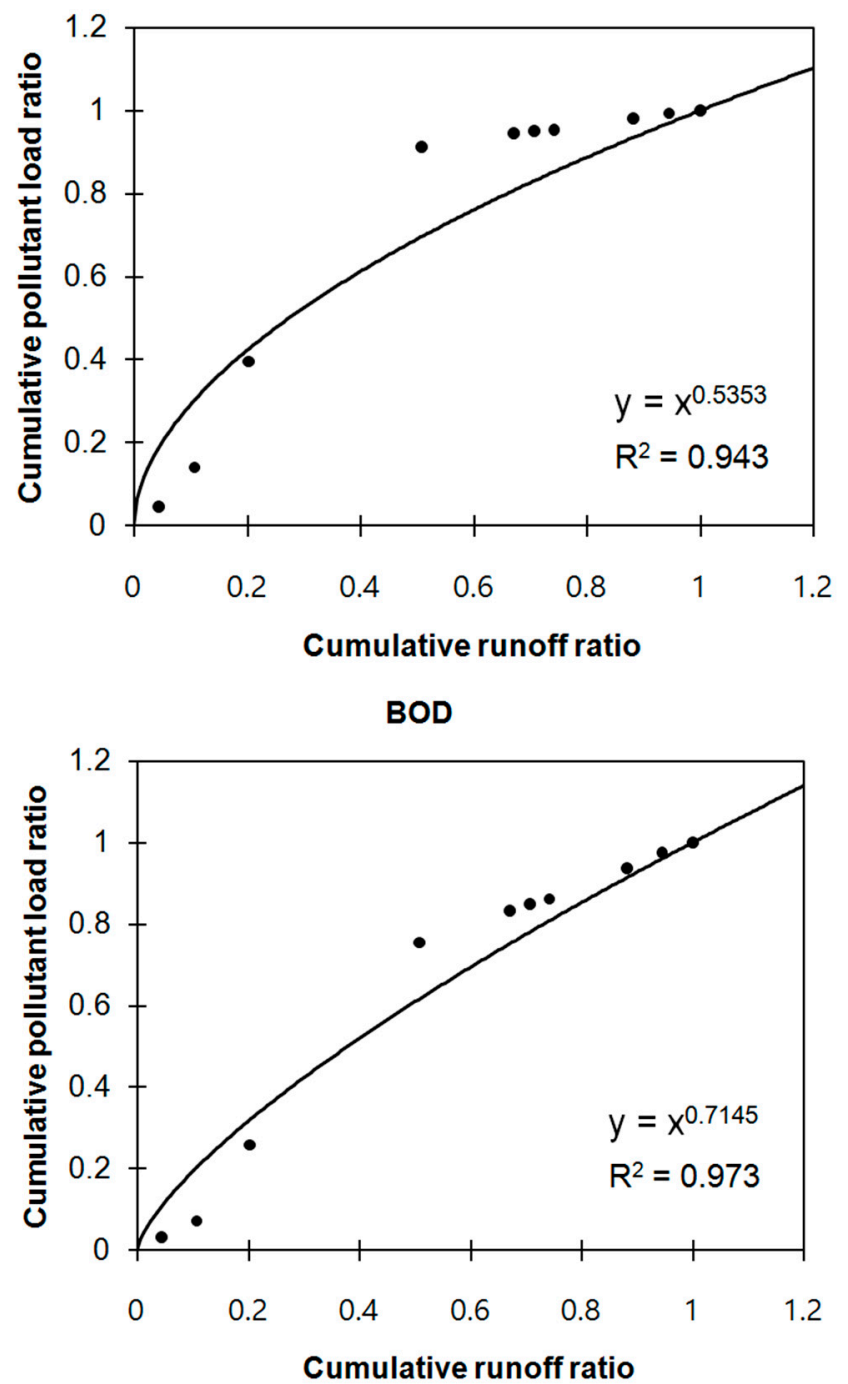

TP

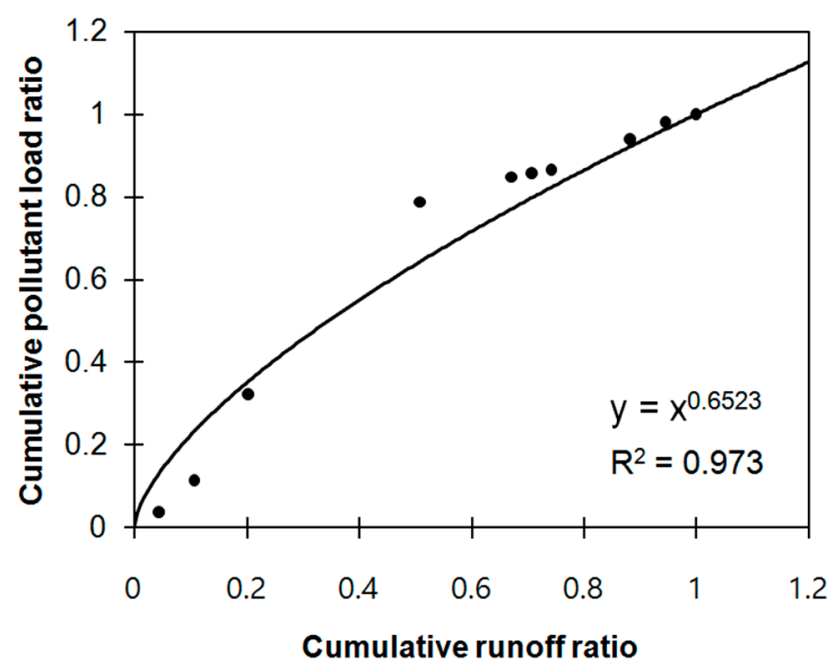

Figure 7. $M(V)$ curve fitting using the power function for Naedongcheon (16-17 July 2016). 
SS

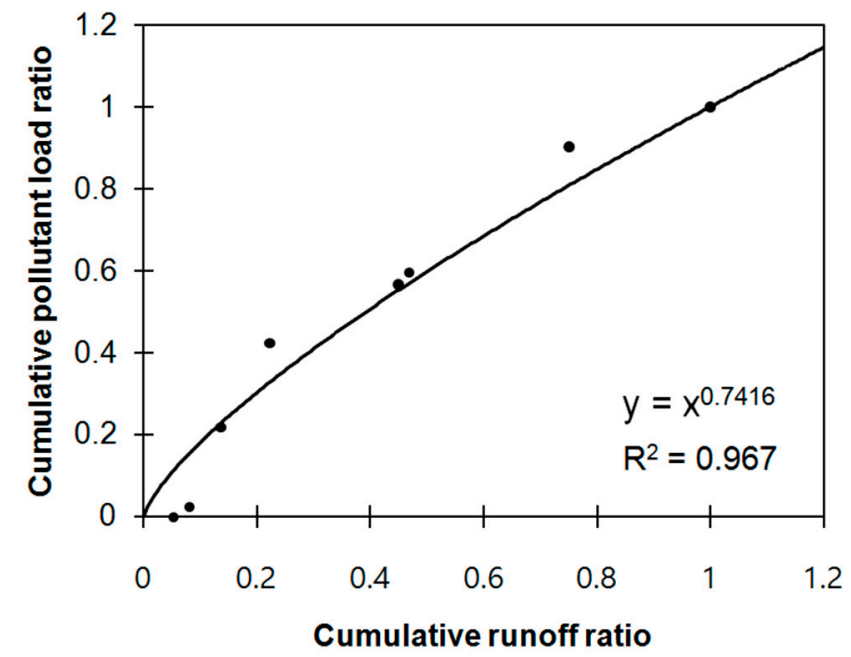

BOD

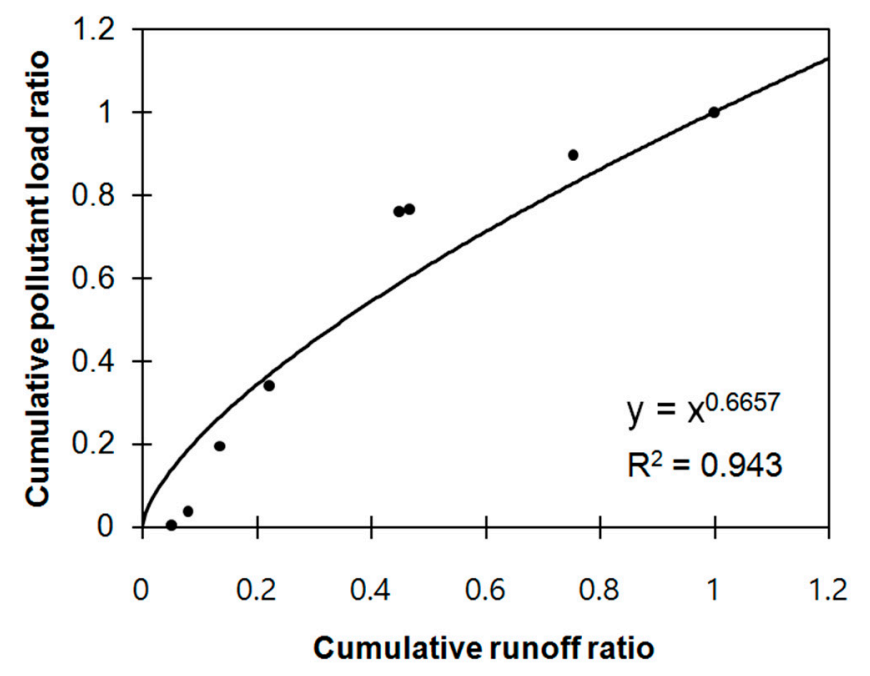

TP

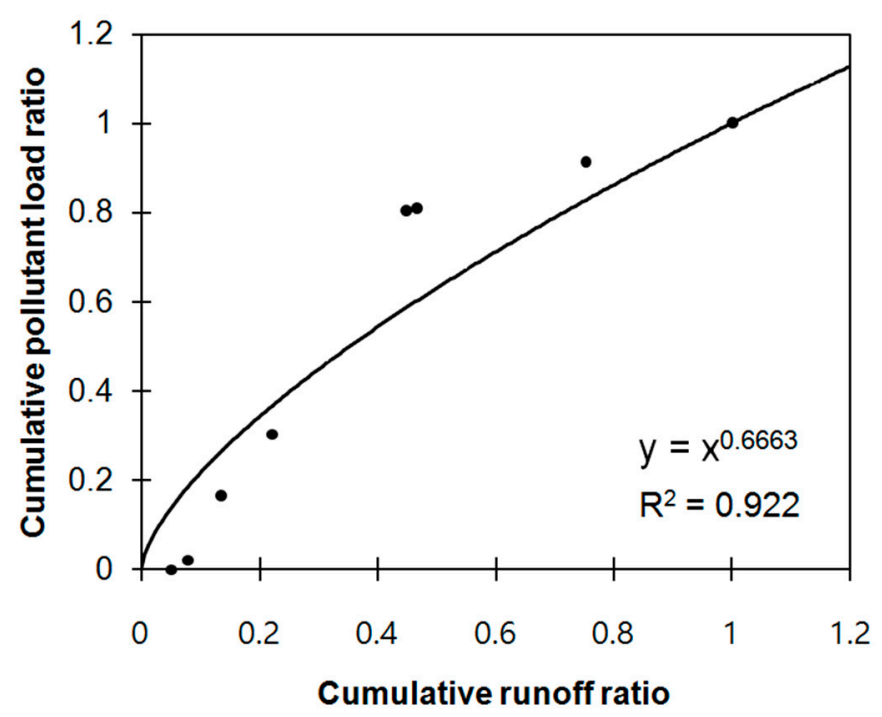

Figure 8. $M(V)$ curve fitting using the power function for Naedongcheon (2-3 October 2016). 
SS

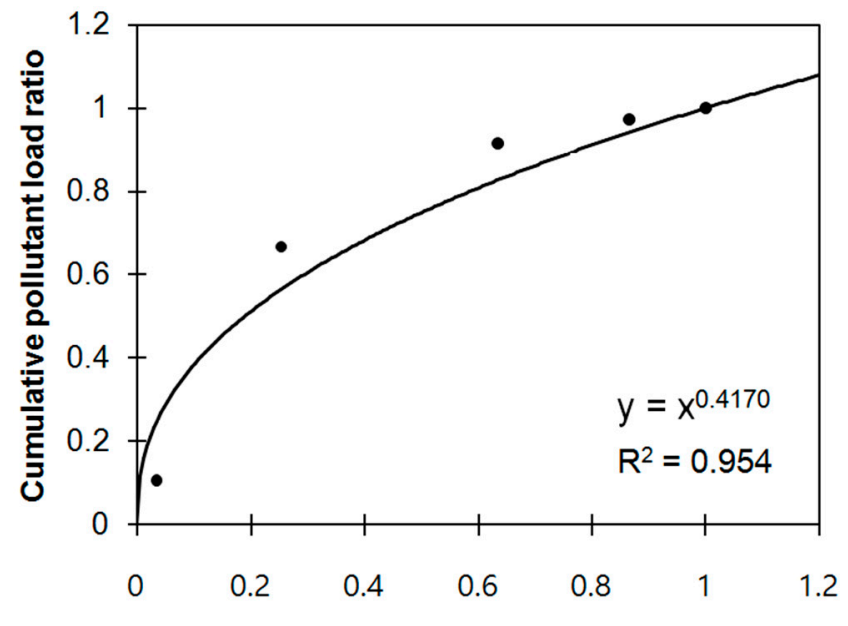

Cumulative runoff ratio

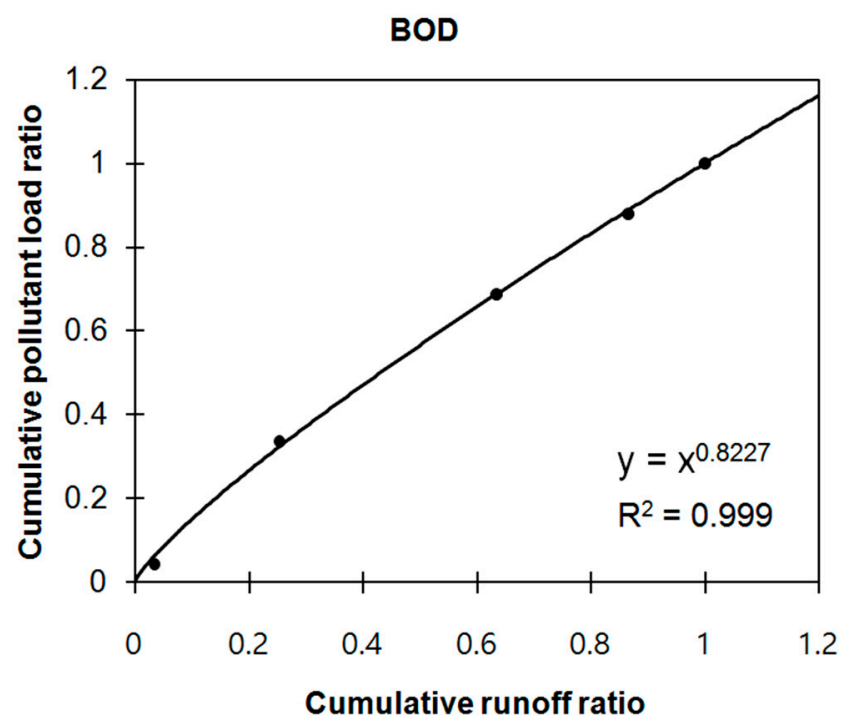

TP

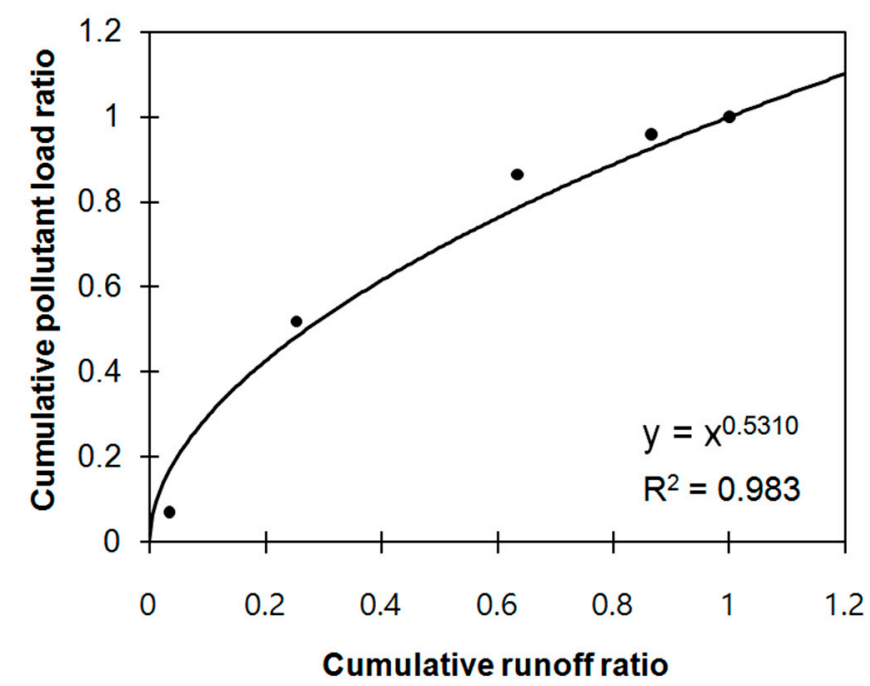

Figure 9. $M(V)$ curve fitting using the power function for Jungjohangcheon (1-2 July 2016). 
SS

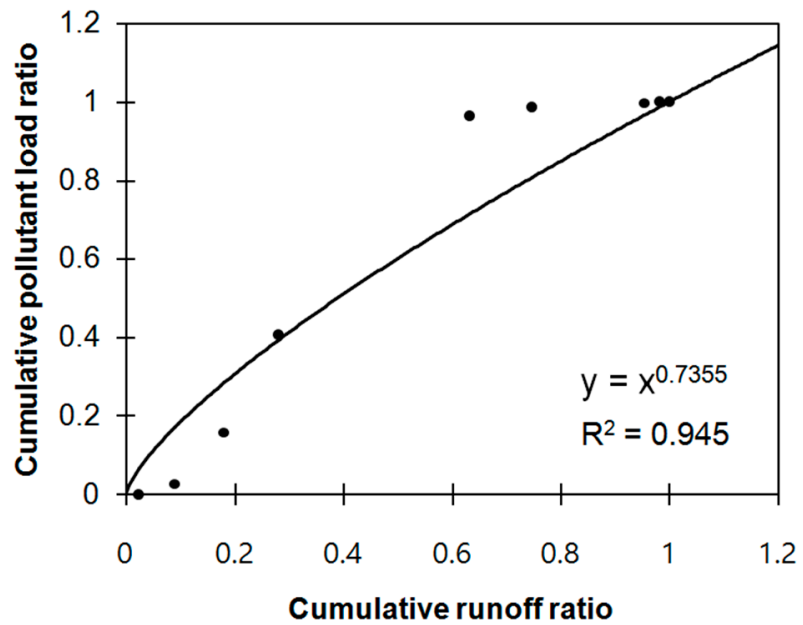

BOD

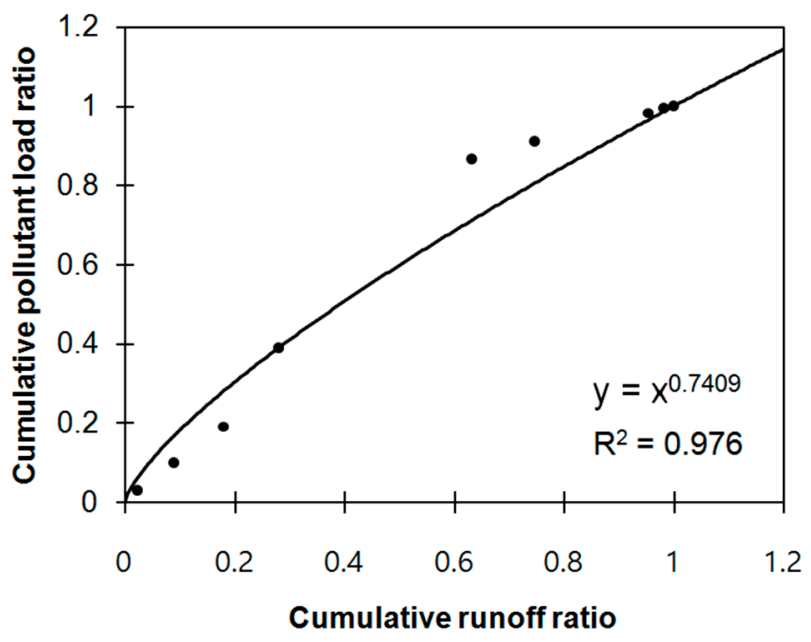

TP

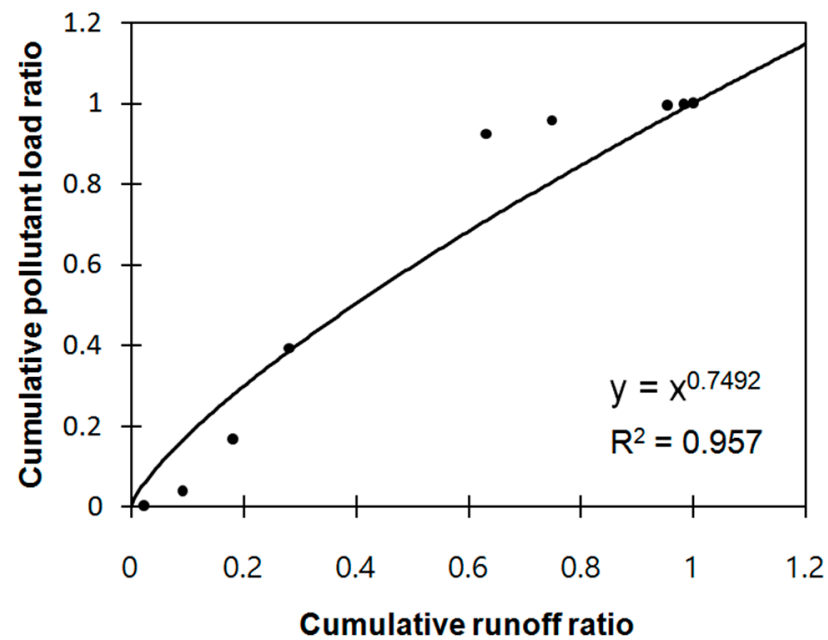

Figure 10. $M(V)$ curve fitting using the power function for Jungjohangcheon (16-17 July 2016). 
ss

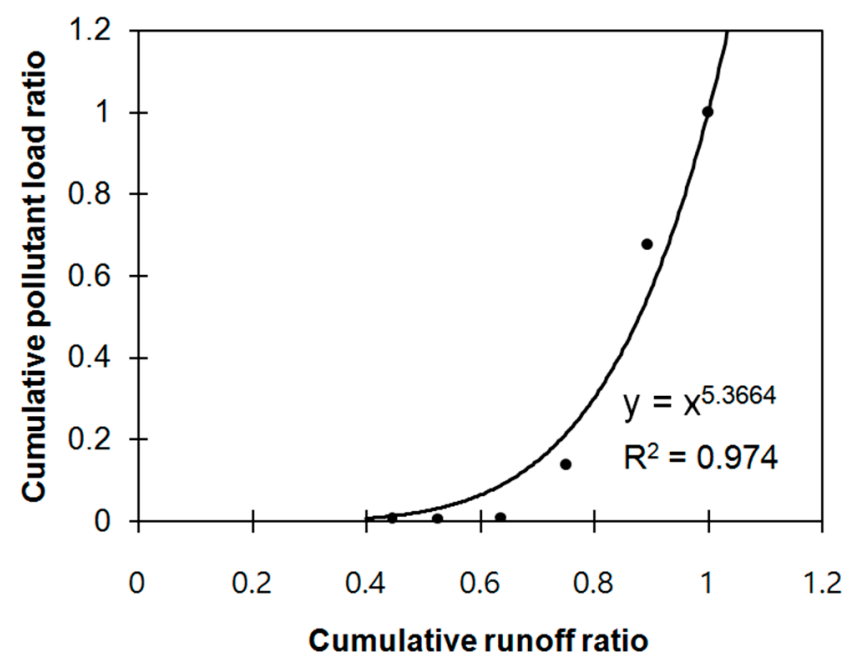

BOD

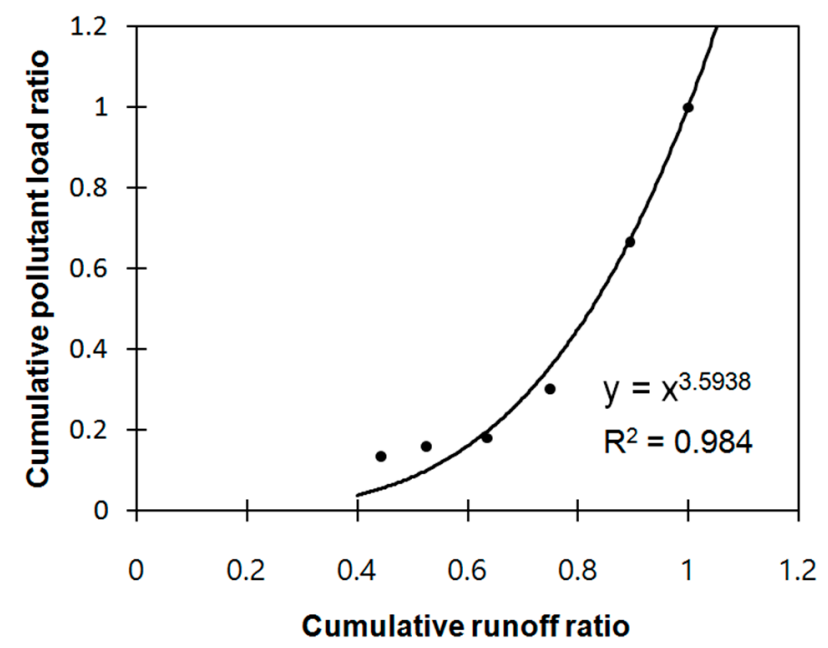

TP

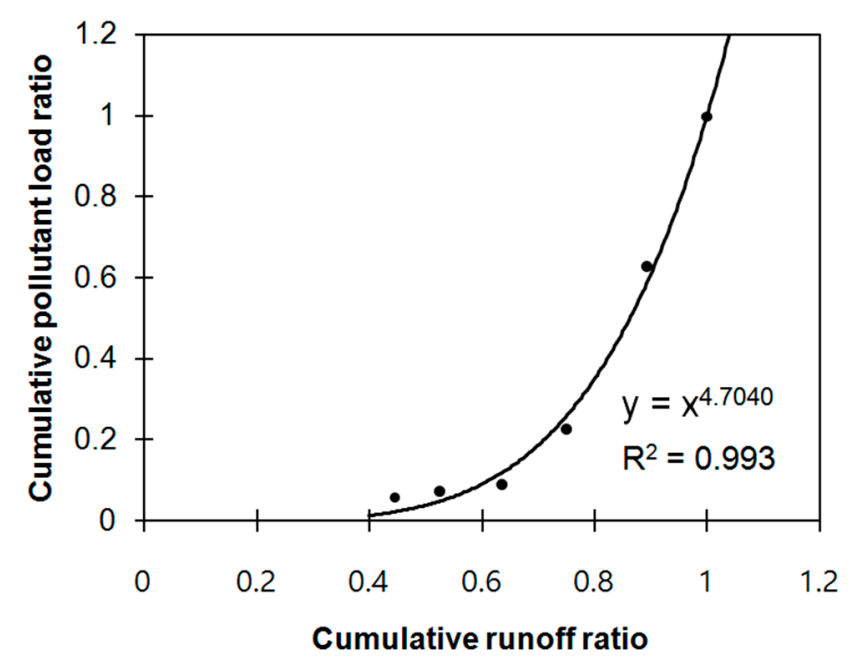

Figure 11. $M(V)$ curve fitting using the power function for Jungjohangcheon (1-3 October 2016). 
SS

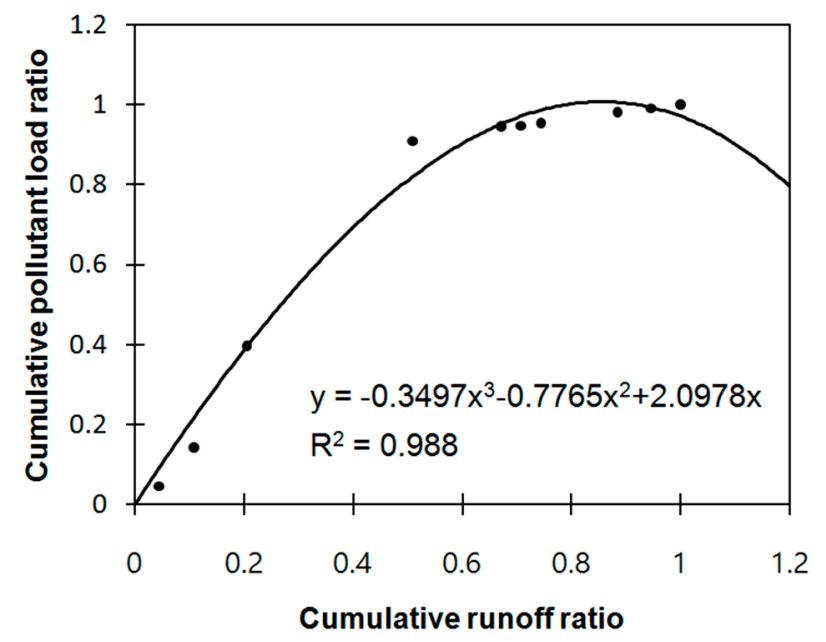

BOD

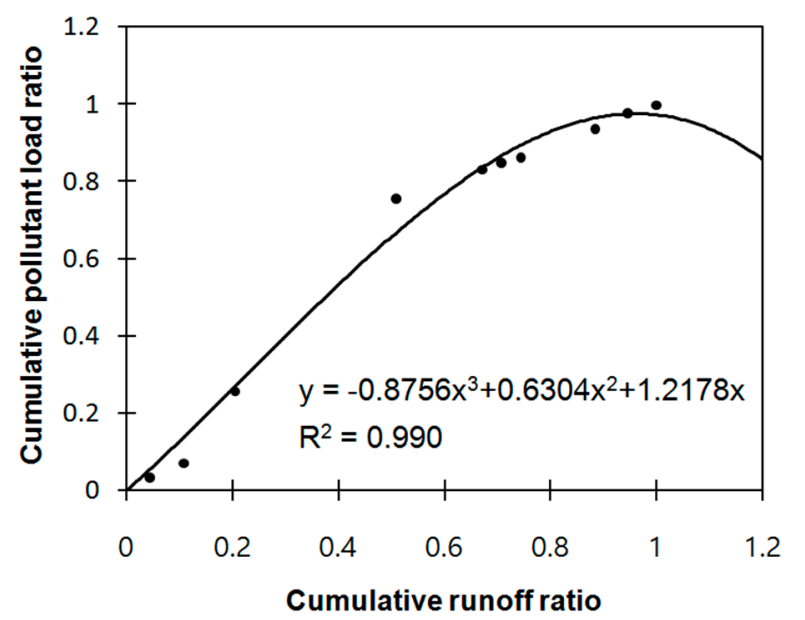

TP

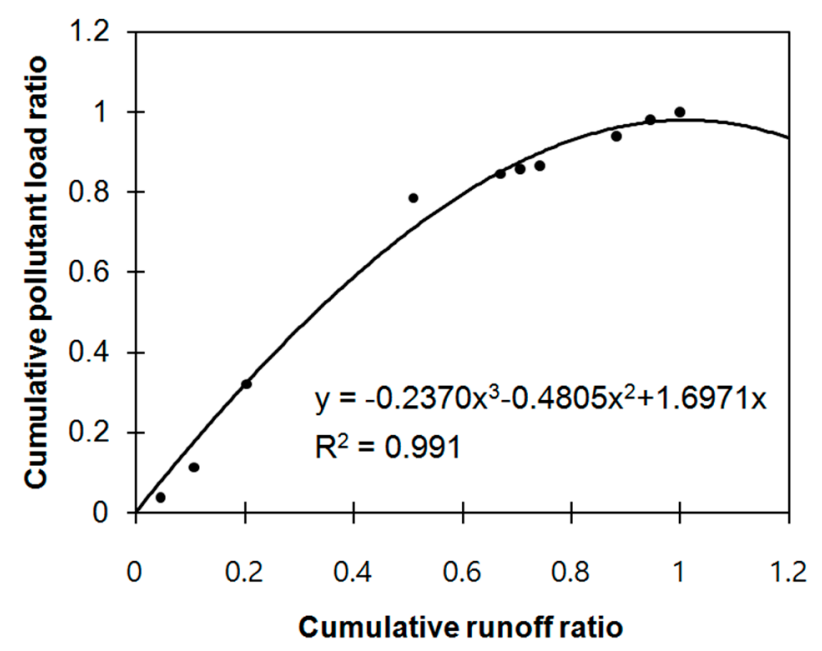

Figure 12. $M(V)$ curve fitting using the third-degree polynomial function for Naedongcheon (16-17 July 2016).

In this study, the first flush phenomenon was analyzed with a regression model using the power function. Table 5 shows that the $R^{2}$ values ranged from 0.922 to 0.999 and the RMSE values ranged 
from 0.012 to 0.149 , which indicates a good performance of the regression models. In the $M(V)$ curve fitting with the power function, the tendency for a strong first flush effect was observed when coefficient $a$ decreased to less than 1.0. Further regression curves are substantially above the $45^{\circ}$ line in Figures 7-10, and coefficient $a$ in Table 5 is decreased. Thus, the strength of the first flush can be interpreted with coefficient $a$ of the regression model using the power function. Coefficient $a$ in Table 5 indicates that a relatively strong first flush occurred because of the SS discharge of Jungjohangcheon and Naedongcheon, and a partial first flush occurred because of the TP and BOD discharge.

Table 5. Nonlinear regression analysis between the cumulative runoff mass and volume data using the power function and $\mathrm{FF}_{30}$ and $\mathrm{FF}_{25}$ values for selected rainfall events.

\begin{tabular}{|c|c|c|c|c|c|c|c|}
\hline Survey Site & Date & $\begin{array}{c}\text { Water } \\
\text { Quality }\end{array}$ & Coefficient $a$ & $R^{2}$ & RMSE & $\mathrm{FF}_{30}$ & $\mathrm{FF}_{25}$ \\
\hline \multirow{6}{*}{ Naedongcheon } & \multirow{3}{*}{ 16-17 July } & SS & 0.535 & $\begin{array}{c}0.943 \\
(0.988)\end{array}$ & $\begin{array}{c}0.125 \\
(0.052)\end{array}$ & 0.64 & 0.40 \\
\hline & & BOD & 0.714 & $\begin{array}{c}0.973 \\
(0.990)\end{array}$ & $\begin{array}{c}0.082 \\
(0.047)\end{array}$ & 0.48 & 0.26 \\
\hline & & $\mathrm{TP}$ & 0.652 & $\begin{array}{c}0.973 \\
(0.991)\end{array}$ & $\begin{array}{c}0.079 \\
(0.045)\end{array}$ & 0.53 & 0.32 \\
\hline & \multirow{3}{*}{ 2-3 October } & SS & 0.742 & 0.967 & 0.082 & 0.47 & 0.44 \\
\hline & & BOD & 0.666 & 0.943 & 0.123 & 0.43 & 0.36 \\
\hline & & $\mathrm{TP}$ & 0.666 & 0.922 & 0.149 & 0.40 & 0.33 \\
\hline \multirow{9}{*}{ Jungjohangcheon } & \multirow{3}{*}{ 1-2 July } & SS & 0.417 & 0.954 & 0.098 & 0.71 & 0.67 \\
\hline & & BOD & 0.823 & 0.999 & 0.012 & 0.38 & 0.34 \\
\hline & & $\mathrm{TP}$ & 0.531 & 0.983 & 0.067 & 0.57 & 0.52 \\
\hline & \multirow{3}{*}{ 16-17 July } & SS & 0.735 & 0.945 & 0.130 & 0.466 & 0.331 \\
\hline & & BOD & 0.741 & 0.976 & 0.078 & 0.431 & 0.328 \\
\hline & & $\mathrm{TP}$ & 0.749 & 0.957 & 0.114 & 0.442 & 0.326 \\
\hline & \multirow{3}{*}{ 1-3 October } & SS & 5.366 & 0.974 & 0.076 & 0.005 & 0.004 \\
\hline & & BOD & 3.594 & 0.984 & 0.051 & 0.089 & 0.075 \\
\hline & & $\mathrm{TP}$ & 4.704 & 0.993 & 0.033 & 0.039 & 0.032 \\
\hline
\end{tabular}

Note: Values in parentheses are the results of regression model using a third-degree polynomial function.

The $\mathrm{FF}_{30}$ from four rainfall events for a highly urbanized area in China, which had a drainage area of 115-218 ha, a percentage of urban area of $62.5-90.1 \%$, and a rainfall depth of 6.3-57.8 mm, ranged from 0.189 to $0.614\left(\mathrm{COD}, \mathrm{NH}_{3}-\mathrm{N}, \mathrm{TN}, \mathrm{TP}, \mathrm{SS}\right.$, and $\mathrm{BOD}_{5}$ ) (Ma et al., 2011). In addition, for an urban area with a catchment area of $480 \mathrm{ha}$, an impervious surfaces ratio of $85 \%$, and mixed discharge of stormwater runoff and untreated wastewater, the $\mathrm{FF}_{30}$ from 8 rainfall events was $52.2-72.1 \%$ for total SS (TSS), $53.0-65.3 \%$ for COD, $40.4-50.6 \%$ for TN, and $45.8-63.2 \%$ for TP [21].

A significant first flush is assumed to occur if at least $80 \%$ of the total pollutant mass is transported in the first $30 \%$ of the volume discharged during rainfall events (i.e., a $30 / 80$ first flush) [12]. However, Sansalone and Buchberger [31] proposed a 25/50 first flush. In both cases, these values are generally used for concentrated gutter flow where the first flush effect was assumed to be strong [12].

The significance and the characteristics of first flushes in medium-sized agricultural catchments on the French Mediterranean coast were investigated. The highest $\mathrm{FF}_{25}$ value of the agricultural catchments for a flood was 0.72 , and it was calculated using the TSS value. Vorreiter and Hickey [32] defined a first flush at a $\mathrm{FF}_{25}$ value greater than 0.4-0.6. The $\mathrm{FF}_{25}$ for a weak flood is approximately $42 \%$ according to the TSS value, which still meets the criteria of Vorreiter and Hickey [22,32].

The $\mathrm{FF}_{30}$ and $\mathrm{FF}_{25}$ values were estimated based on the five events in Naedongcheon and Jungjohangcheon and are shown in Table 5. Among the five $\mathrm{FF}_{25}$ values for the SS values in Table 5, three $\mathrm{FF}_{25}$ values $(0.40,0.44$, and 0.67$)$ meet the criteria of a first flush $\left(\mathrm{FF}_{25}\right.$ 0.4). The $\mathrm{FF}_{30}$ values in Table 5 are inversely proportional to coefficient $a$ values of the regression model. Parameter $a$ of the SS load from 1-2 July at Jungjohangcheon (0.417) is the lowest among the coefficient $a$ values in Table 5, and the $\mathrm{FF}_{30}$ of the $\mathrm{SS}$ load for the same event (0.708) is the highest among all $\mathrm{FF}_{30}$ values. However, 
the coefficient $a$ of the SS load from 1 to 3 October at Jungjohangcheon (5.366) is the highest among the coefficient $a$ values shown in Table 5, and the $\mathrm{FF}_{30}$ value of the SS load for the same event (0.005) is the lowest among all $\mathrm{FF}_{30}$ values.

\subsubsection{EMC and Pollutant Loads per Unit Area}

As shown in Table 6, the EMC values for 1-2 July from the Jaun area points (Figure 1) indicate that the highest SS values occur in Jungjohangcheon, whereas the EMC gradually reduces as the flow continues downstream through Johangcheon to the lower part of Jauncheon. The remaining water quality parameters do not show specific trends. The EMC values for 16-17 July from the points in the Mandae area (Figure 1) indicate that the SS is highest in Naedongcheon. The EMC during a rainfall event gradually decreases as the flow continues through Mandaecheon and Inbukcheon downstream. Although the Soyang River point is mostly in the downstream part of the study area, on 3 October 2016, two samples from the Soyang River point have an SS concentration over $200 \mathrm{mg} / \mathrm{L}$. The EMC of the SS loads in the storm event from 1 October to 3 October 2017 is atypically high because of construction work near the survey point.

Table 6. EMC of each rainfall event in the Lake Soyang watershed.

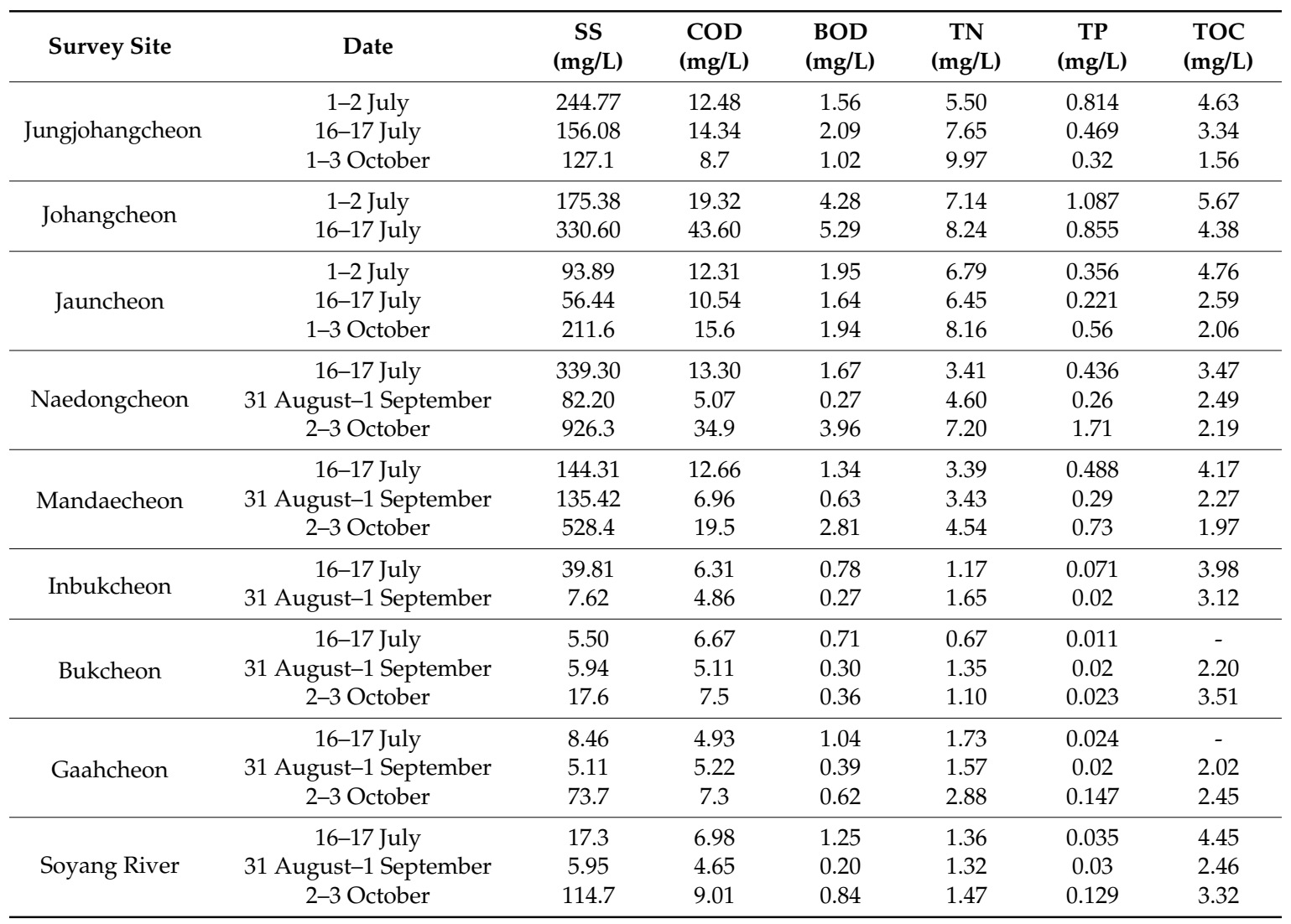

In the Mandae area (Figure 1), the SS pollutant loads per unit area is the largest in Naedongcheon, which is the point furthest upstream, and decreases with the flow towards Mandaecheon and Inbukcheon (Table 7). The TN, TP, and TOC pollutant loads are higher in the upper part and also display declining trends with flow downstream. In the Jaun area (Figure 1), the SS pollutant load per unit area is not always highest at the Jungjohangcheon point, with variation observed among the rainfall events. The loads of the pollutants other than SS do not show specific trends. 
Table 7. Pollutant loads per unit area of each rainfall event in the Lake Soyang watershed.

\begin{tabular}{|c|c|c|c|c|c|c|c|c|}
\hline Survey Site & $\begin{array}{c}\text { Sub-Basin } \\
\text { Area (ha) }\end{array}$ & Date & $\begin{array}{c}\text { SS } \\
(\mathrm{kg} / \mathrm{ha})\end{array}$ & $\begin{array}{l}\text { COD } \\
\text { (kg/ha) }\end{array}$ & $\begin{array}{c}\text { BOD } \\
\text { (kg/ha) }\end{array}$ & $\begin{array}{c}\mathrm{TN} \\
(\mathrm{kg} / \mathrm{ha})\end{array}$ & $\begin{array}{c}\text { TP } \\
(\mathrm{kg} / \mathrm{ha})\end{array}$ & $\begin{array}{c}\text { TOC } \\
\text { (kg/ha) }\end{array}$ \\
\hline \multirow{3}{*}{ Jungjohangcheon } & \multirow{3}{*}{1020} & 1-2 July & 25.5 & 1.3 & 0.2 & 0.570 & 0.084 & 0.48 \\
\hline & & 16-17 July & 25.3 & 2.3 & 0.3 & 1.240 & 0.076 & 0.54 \\
\hline & & 1-3 October & 3.79 & 0.26 & 0.030 & 0.298 & 0.0096 & 0.047 \\
\hline \multirow{2}{*}{ Johangcheon } & \multirow{2}{*}{4036} & 1-2 July & 16.1 & 1.8 & 0.4 & 0.650 & 0.098 & 0.51 \\
\hline & & 16-17 July & 63.2 & 8.3 & 1.0 & 1.570 & 0.163 & 0.83 \\
\hline \multirow{3}{*}{ Jauncheon } & \multirow{3}{*}{13,426} & 1-2 July & 12.4 & 1.6 & 0.3 & 0.900 & 0.046 & 0.63 \\
\hline & & 16-17 July & 9.6 & 1.8 & 0.3 & 1.090 & 0.037 & 0.44 \\
\hline & & 1-3 October & 3.22 & 0.24 & 0.029 & 0.124 & 0.0085 & 0.031 \\
\hline \multirow{3}{*}{ Naedongcheon } & \multirow{3}{*}{467} & 16-17 July & 136.8 & 5.4 & 0.7 & 1.370 & 0.175 & 1.40 \\
\hline & & 31 August-1 September & 6.10 & 0.38 & 0.021 & 0.342 & 0.0198 & 0.185 \\
\hline & & 2-3 October & 70.82 & 2.67 & 0.303 & 0.551 & 0.1309 & 0.167 \\
\hline \multirow{3}{*}{ Mandaecheon } & \multirow{3}{*}{6080} & 16-17 July & 22.1 & 1.9 & 0.2 & 0.510 & 0.074 & 0.63 \\
\hline & & 31 August-1 September & 14.33 & 0.74 & 0.067 & 0.363 & 0.03171 & 0.240 \\
\hline & & 2-3 October & 34.79 & 1.28 & 0.185 & 0.299 & 0.0482 & 0.130 \\
\hline \multirow{2}{*}{ Inbukcheon } & \multirow{2}{*}{49,898} & $16-17$ July & 4.6 & 0.7 & 0.1 & 0.130 & 0.008 & 0.45 \\
\hline & & 31 August-1 September & 0.33 & 0.21 & 0.012 & 0.072 & 0.00100 & 0.135 \\
\hline \multirow{3}{*}{ Bukcheon } & \multirow{3}{*}{28,817} & 16-17 July & 0.5 & 0.6 & 0.1 & 0.059 & 0.001 & - \\
\hline & & 31 August-1 September & 0.23 & 0.20 & 0.012 & 0.052 & 0.00066 & 0.086 \\
\hline & & 2-3 October & 1.71 & 0.73 & 0.035 & 0.107 & 0.0022 & 0.125 \\
\hline \multirow{3}{*}{ Gaahcheon } & \multirow{3}{*}{4732} & 16-17 July & 1.1 & 0.6 & 0.1 & 0.220 & 0.003 & - \\
\hline & & 31 August-1 September & 0.13 & 0.13 & 0.0098 & 0.040 & 0.00039 & 0.051 \\
\hline & & 2-3 October & 1.28 & 0.13 & 0.010 & 0.050 & 0.0025 & 0.026 \\
\hline \multirow{3}{*}{ Soyang River } & \multirow{3}{*}{199,202} & $16-17$ July & 2.2 & 0.9 & 0.2 & 0.176 & 0.005 & 0.58 \\
\hline & & 31 August-1 September & 0.28 & 0.22 & 0.009 & 0.061 & 0.00126 & 0.115 \\
\hline & & 2-3 October & 6.403 & 0.503 & 0.047 & 0.082 & 0.0072 & 0.186 \\
\hline
\end{tabular}

The Mandaecheon sub-basin has the highest sediment yields among the Soyang River sub-basin, and it consists of $27.7 \%$ agricultural land. The remaining non-agricultural land is composed of $20.7 \%$ forest area, $51.6 \%$ residential land, and other areas. The agricultural land consists of $75 \%$ dry field areas. The Mandae area is a dense highland field area and represents a major sediment runoff source. Large amounts of pollutants are discharged into the river because the agricultural population in this area is larger than those of the other areas and because military units are also in this area. Thus, the EMC and pollutant load per unit area for the SS and TP in the Mandaecheon and Naedongcheon sub-basin areas are higher than those of the other areas.

\subsection{Water Quality Variations of the Management Target Point in the Lake Soyang Watershed}

The water quality management target point within the watershed is the Lake Soyang Dam effluent. The monthly turbidity survey results (since 2003) are presented in Figure 13. Typically, turbidity in Lake Soyang is high in the summer because heavy rains are concentrated in this period and high levels of sediments are discharged from the highland fields. Because of the influence of typhoon Ewiniar in 2006 , these results show high turbidity levels of 272.1 NTU. Since 2008, the management goal of less than 50 NTU of turbidity has been maintained. The general turbidity of the Lake Soyang Dam effluent was low in 2012, 2014, and 2015 because of low rainfall amounts, as shown in Table 2. In accordance with the monthly distribution, the turbidity from August, September, and October is high because of summer rainfall. 


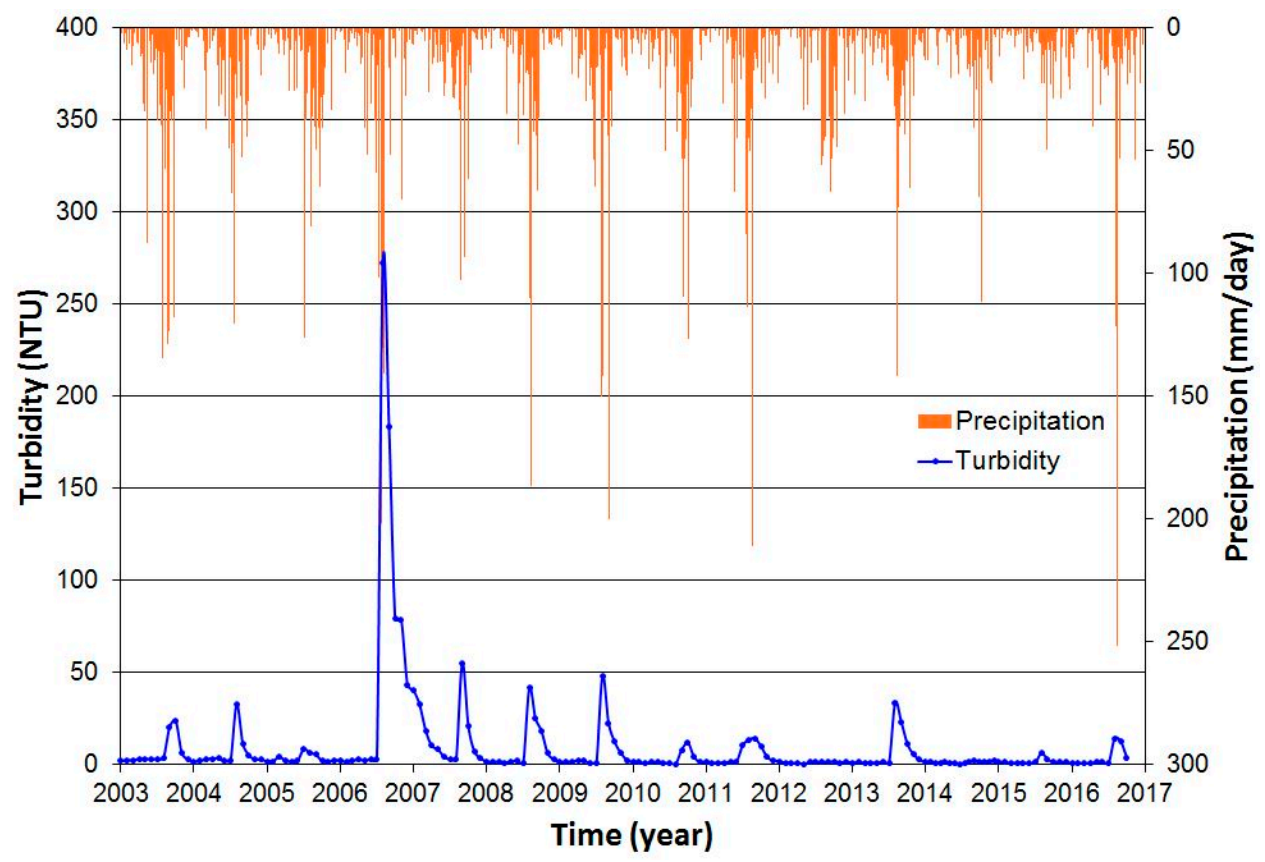

Figure 13. Turbidity variation of the Lake Soyang Dam effluent.

The turbidity trends in the lake are also apparent from the results of the additive seasonal trend decomposition [27] (Figure 14). Time series of the precipitation and turbidity was decomposed using the seasonal decomposition option of the time series transformation tool in the XLSTAT. Additive model was used and the period was set to 12 for a one-year periodicity on monthly data. A long-term turbidity trend was approximately coincident with the trend in long-term precipitation. However, extremely high turbidity in the summer of 2006 was observed following $670 \mathrm{~mm}$ of heavy rain that fell over eight days at a maximum rate of $66 \mathrm{~mm}$ per hour in July 2006.
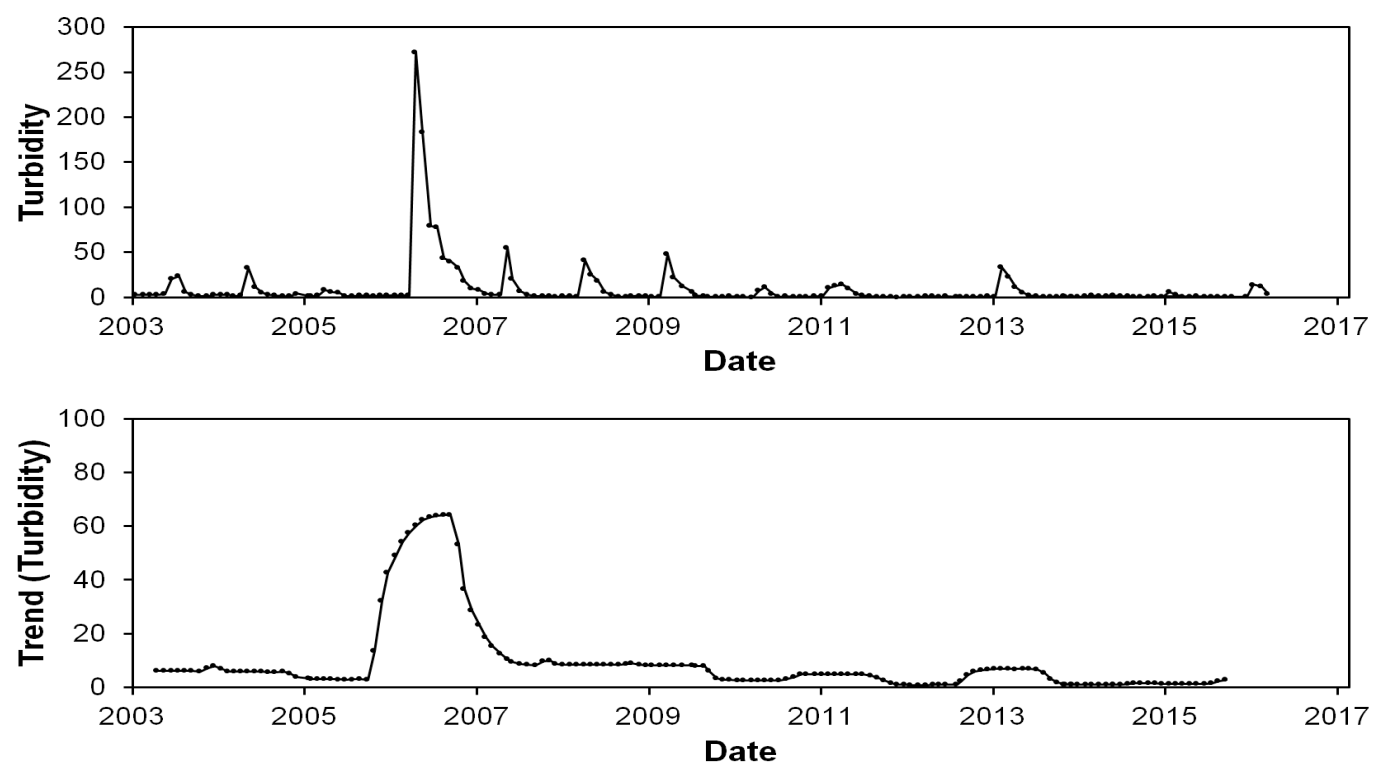

Figure 14. Cont. 

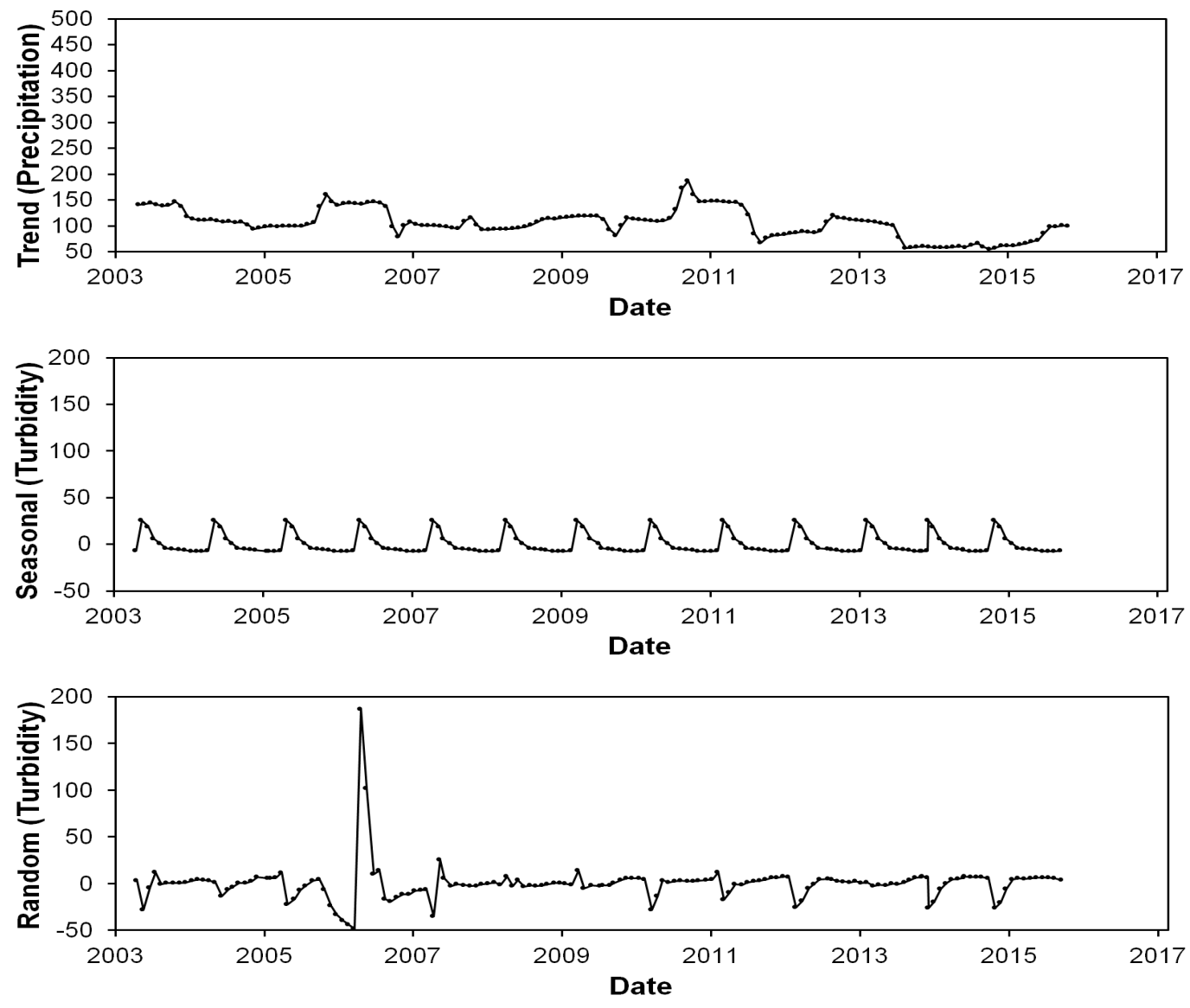

Figure 14. Long term seasonal trend decomposition for monthly turbidity and precipitation in the Lake Soyang.

\subsection{Investigation of the Actual Management Conditions of BMPs Targeting Farmers and Effective Turbid Water Management}

We investigated the actual management condition of BMPs by targeting the farmers in the Mandae, Gaah, and Jaun areas, which frequently present turbid water, over two days (4 November 2016, and 11 November 2016). Overall, 14 questions were answered by 35 farmers in the Mandae area, 19 farmers in the Gaah area, and 32 from the Jaun area.

The results of the survey [9] indicated that many of the farmers did not receive the special education or the promotional materials required by the BMPs. Nevertheless, farmers were well aware of the turbid water reduction plan. In the farmers' opinion, during rainfall events, muddy water appeared most severe in the highland field areas, and a secondary occurrence was observed in the forest areas and adjacent forest roads. The participation rate for farmers utilizing the government-run muddy water reduction plan for highland fields was $50 \%$, and most of the farmers agreed to participate in the muddy water reduction plans for the highland field areas. The most effective pre-emptive countermeasure was the involvement of the government and an expansion of the budget. Twice as many respondents indicated that turbid water reduction facilities from the highland field area should be managed by farmers rather than a public official. A greater number of responses indicated that among the current sediment reduction implementations, sedimentation basins and slope protection are efficient. Most of the answers showed that the turbid water management plan improved the cleanliness of the lake.

For turbid water reduction, approximately $55 \%$ of the farmers showed an intention to proceed with rye seeding in furrows, approximately $38 \%$ indicated that they will continue conventional cultivation, and $7 \%$ indicated that they would conduct rice straw mat mulching. In support of rye seeding and rice 
straw mat mulching processes, $71 \%$ of the farmers wanted rye seeds and rice straw mats and $29 \%$ of the farmers wanted the incentive.

In the highland area, to decrease the damage caused by the continuous cultivation of economic crops, manage pests, maximize the crop productivity and improve soil fertility, $30-50 \mathrm{~cm}$ of soil dressing has been applied to the top layer of soil. This soil dressing is a significant reason for the sediment discharge of the highland fields. Green manure fertilization and decreasing the field slope are suggested as realistic methods of reducing the amount of soil dressing.

For turbid water reduction in the nonpoint source pollution management area, both structural and non-structural methods are necessary. The structural BMPs, such as gabion walls, grassed swales, slope protection work, sedimentation basins, and concrete channels, require appropriate management and installation. Additionally, non-structural methods are available, including surface coverage, crop conversion, reduction of tillage, improvement of plowing time, contour cropping, optimization of farming time, soil structure improvement, and crop rotation.

The construction of gabion walls is implemented for the prevention of sediment runoff because of soil dressing. However, the field's original surface height is increasing; therefore, the gabion walls are not fulfilling their function. Suggesting and promulgating an appropriate height of soil dressing for farmers, creating a grassland buffer on the edge of the highland fields, and identifying the amount of harvest reduction should be considered in this area. In this regard, a management plan that includes a balance of structural methods and non-structural methods will maximize the efficiency of muddy water management.

\section{Conclusions}

A storm water runoff survey was conducted at 10 survey points in the Soyang River basin. In the most upstream part of the basin where highland fields are densely distributed, large variations in nutrient concentrations, such as SS, TP, and TN concentrations, were observed, and the mean values of water quality were high. The maximum SS concentration at Jungjohangcheon and Naedongcheon were $1152 \mathrm{mg} / \mathrm{L}$ and $4598 \mathrm{mg} / \mathrm{L}$, respectively.

In the Jaun area, the SS concentration based on the EMC at each point was the highest in Jungjohangcheon, and the EMC tended to decrease as the flow passed through Johangcheon and Jauncheon and continued downstream. Throughout the research period, the EMC of Jungjohangcheon ranged from a maximum of $244.8 \mathrm{mg} / \mathrm{L}$ to a minimum of $127.1 \mathrm{mg} / \mathrm{L}$. In Jauncheon, the EMC ranged from a maximum of $211.6 \mathrm{mg} / \mathrm{L}$ to a minimum of $56.4 \mathrm{mg} / \mathrm{L}$.

In the Mandae area, the SS concentration based on the EMC at each point was the highest in Naedongcheon, and the EMC tended to decrease as the flow passed through Mandaecheon and Inbukcheon and continued downstream during the rainfall event. Throughout the survey period, the EMC of Naedongcheon ranged from a maximum of $926.3 \mathrm{mg} / \mathrm{L}$ to a minimum of $82.2 \mathrm{mg} / \mathrm{L}$. In the Soyang River, the EMC ranged from a maximum of $114.7 \mathrm{mg} / \mathrm{L}$ to a minimum of $5.8 \mathrm{mg} / \mathrm{L}$. The Mandae area, which includes Naedongcheon and Mandaecheon, has a high ratio of highland field areas and a large agricultural population and hosts military units. Thus, excessive soil erosion occurs and a large amount of sediments and pollutants are discharged. The EMC and pollutant load per unit area for the SS and TP in Naedongcheon and Mandaecheon were higher than those of the other areas.

From the Mandae area, the pollutant loads per unit area for each SS measurement show that the highest value occurs in Naedongcheon, which is the point furthest upstream. This value is reduced as the flow continues toward the lower part of the Soyang River. The pollutant loads, such as TN, $\mathrm{TP}$, and TOC, display a similar tendency. In the Jaun area, the upper part of Jungjohangcheon does not always show the highest SS load per unit area, and different patterns are observed depending on the rainfall event. With the exception of the SS load, the water quality pollutant loads do not show specific trends.

The turbidity of the Lake Soyang Dam, which is located in the lower part of the Soyang River, depends largely on the annual precipitation characteristics. Thus, the low observed turbidity is related 
to the light precipitation during the year, which results in a low amount of nutrient runoff from the highland fields. In accordance with the monthly distribution, the turbidity from August, September, and October is high because of summer rainfall.

Previous research has shown that the first flush mainly occurs in paved urban areas [33-37]. However, a large amount of sediments are discharged from the highland fields of the upper part of the Soyang River basin because of soil erosion during extreme rainfall events. We found that the first flush phenomenon occurs for certain rainfall events in the highland field dense area. As indicated by the $M(V)$ curves of Naedongcheon and Jungjohangcheon, during a considerable number of rainfall events, many of the mass and volume data points occur above the $45^{\circ}$ straight line.

The results of the power function and polynomial function are compared to identify the appropriate functional formula for the $M(V)$ curve. We concluded that the power function is the better than the polynomial function in this area. For the power function, the $R^{2}$ values at Naedongcheon and Jungjohangcheon range from 0.922 to 0.999 and the RMSE values range from 0.012 to 0.149 , which indicate good performance of the regression models. Furthermore, the coefficient value of the power function indicates the intensity of the first flush, which can also be identified by the $\mathrm{FF}_{30}$ and $\mathrm{FF}_{25}$ analysis. The maximum $\mathrm{FF}_{30}$ and $\mathrm{FF}_{25}$ in this study are 0.71 and 0.67 , respectively, which are fairly high values. Although the observed rainfall events are not floods and the land use is not urban but agricultural land, certain rainfall events show a strong first flush.

It is important to build new BMPs, such as gabion walls, grassed swales, slope protection work, sedimentation basins, and concrete channels, in the area of concern. Maintenance management of the current facilities is also important to obtain the maximum efficacy of turbid water management. The cultivating farmers from the nearby areas have the best understanding of the drawbacks and efficacy of the reduction facilities. In addition, many farmers have stated that it would be better for them to directly manage the turbid water reduction facilities; thus, a BMP management system of voluntary farmers should be implemented. Most of the farmers intended to participate in the muddy water reduction work; therefore, the involvement of local government and active education from government-related organizations are important for the reduction of muddy water.

Acknowledgments: This research was supported by the Wonju Regional Environmental Office and the Basic Science Research Program through the National Research Foundation of Korea (NRF) funded by the Ministry of Education (grant number: NRF-2017R1D1A1B03032816).

Author Contributions: Jae Heon Cho designed research, conducted data analysis and wrote the paper. Jong Ho Lee contributed to the discussion and writing of the paper.

Conflicts of Interest: The authors declare no conflicts of interest.

\section{References}

1. Shi, Z.H.; Cai, C.F.; Ding, S.W.; Wang, T.W.; Chow, T.L. Soil conservation planning at the small watershed level using RUSLE with GIS: A case study in the Three Gorge Area of China. Catena 2004, 55, $33-48$. [CrossRef]

2. Jang, S.S.; Ahn, S.R.; Kim, S.J. Evaluation of executable best management practices in Haean highland agricultural catchment of South Korea using SWAT. Agric. Water Manag. 2017, 180, 224-234. [CrossRef]

3. Ramos, T.B.; Gonçalves, M.C.; Branco, M.A.; Brito, D.; Rodrigues, S.; Sánchez-Pérez, J.M.; Sauvage, S.; Prazeres, Â.; Martins, J.C.; Fernandes, M.L.; et al. Sediment and nutrient dynamics during storm events in the Enxoé temporary river, southern Portugal. Catena 2015, 127, 177-190. [CrossRef]

4. Kim, B.; Park, J.H.; Hwang, G.; Jun, M.S.; Choi, K. Eutrophication of reservoirs in South Korea. Limnology 2001, 2, 223-229. [CrossRef]

5. Kim, B.; Jung, S. Turbid storm runoffs in Lake Soyang and their environmental effect. J. KSEE 2007, 29, 1185-1190.

6. Gitau, M.W.; Veith, T.L.; Gburek, W.J. Farm-level optimization of BMP placement for cost-effective pollution reduction. Trans. ASAE 2004, 47, 1923-1931. [CrossRef] 
7. Zhen, X.-Y.; Yu, S.L.; Lin, J.-Y. Optimal Location and Sizing of Stormwater Basins at Watershed Scale. J. Water Resour. Plan. Manag. 2004, 130, 339-347. [CrossRef]

8. Maharjan, G.R.; Ruidisch, M.; Shope, C.L.; Choi, K.; Huwe, B.; Kim, S.J.; Tenhunen, J.; Arnhold, S. Assessing the effectiveness of split fertilization and cover crop cultivation in order to conserve soil and water resources and improve crop productivity. Agric. Water Manag. 2016, 163, 305-318. [CrossRef]

9. Wonju Regional Environmental Office. Monitoring and Assessment for the Nonpoint Source Pollution Management Area of Mandae, Gaah and Jaun Region; Ministry of Environment: Wonju, Korea, 2016.

10. Roman, D.C.; Vogel, R.M.; Schwarz, G.E. Regional regression models of watershed suspended-sediment discharge for the eastern United States. J. Hydrol. 2012, 472-473, 53-62. [CrossRef]

11. Mayerhofer, C.; Meißl, G.; Klebinder, K.; Kohl, B.; Markart, G. Comparison of the results of a small-plot and a large-plot rainfall simulator-Effects of land use and land cover on surface runoff in Alpine catchments. Catena 2017, 156, 184-196. [CrossRef]

12. Bertrand-Krajewski, J.L.; Chebbo, G.; Saget, A. Distribution of pollutant mass vs volume in stormwater discharges and the first flush phenomenon. Water Res. 1998, 32, 2341-2356. [CrossRef]

13. Lee, H.; Lau, S.L.; Kayhanian, M.; Stenstrom, M.K. Seasonal first flush phenomenon of urban stormwater discharges. Water Res. 2004, 38, 4153-4163. [CrossRef] [PubMed]

14. Taebi, A.; Droste, R.L. First flush pollution load of urban stormwater runoff. J. Environ. Eng. Sci. 2004, 309, 301-309. [CrossRef]

15. Bach, P.M.; McCarthy, D.T.; Deletic, A. Redefining the stormwater first flush phenomenon. Water Res. 2010, 44, 2487-2498. [CrossRef] [PubMed]

16. Bedient, P.B.; Characklis, W.G.; Harned, D.A. Stormwater analysis and prediction in Houston. J. Environ. Eng. Div. 1978, 104, 1087-1100.

17. Lee, J.; Bang, K. Characterization of urban stormwater runoff. Water Res. 2000, 34, 1773-1780. [CrossRef]

18. Saget, A.; Chebbo, G.; Bertrand-Krajewski, J.L. The first flush in sewer systems. Water Sci. Technol. 1996, 33, 101-108.

19. Deletic, A. The first flush load of urban surface runoff. Water Res. 1998, 32, 2462-2470. [CrossRef]

20. Lee, J.H.; Yu, M.J.; Bang, K.W.; Choe, J.S. Evaluation of the methods for first flush analysis in urban watersheds. Water Sci. Technol. 2003, 48, 167-176. [PubMed]

21. Li, L.Q.; Yin, C.Q.; He, Q.C.; Kong, L.L. First flush of storm runoff pollution from an urban catchment in China. J. Environ. Sci. 2007, 19, 295-299. [CrossRef]

22. Obermann, M.; Rosenwinkel, K.H.; Tournoud, M.G. Investigation of first flushes in a medium-sized mediterranean catchment. J. Hydrol. 2009, 373, 405-415. [CrossRef]

23. Ma, Z.B.; Ni, H.G.; Zeng, H.; Wei, J.B. Function formula for first flush analysis in mixed watersheds: A comparison of power and polynomial methods. J. Hydrol. 2011, 402, 333-339. [CrossRef]

24. Grum, M.; Aalderink, R.H.; Lijklema, L.; Spliid, H. The underlying structure of systematic variations in the event mean concentrations of pollutants in urban runoff. Water Sci. Technol. 1997, 36, 135-140.

25. Charbeneau, R.J.; Barrett, M.E. Evaluation of methods for estimating stormwater pollutant loads. Water Environ. Res. 1998, 70, 1295-1302. [CrossRef]

26. Cho, J.H.; Yun, S.J. Characterization of stormwater runoff and first flush effect in a eutrophic lake watershed. In Proceedings of the IWA 10th International Specialised Conference on Diffuse Pollution and Sustainable Basin Management, Istanbul, Turkey, 18-22 September 2006.

27. XLSTAT. Statistical Software \& Data Analysis Add-on for Excel. Available online: http://www.xlstat.com/en (accessed on 25 July 2017).

28. Novotny, V.; Olem, H. Water Quality Prevention, Identification and Management of Diffuse Pollution; Van Nostrand Reinhold: New York, NY, USA, 1994; ISBN 0-442-00559-8.

29. Yi, Q.; Li, H.; Lee, J.W.; Kim, Y. Development of EMC-based empirical model for estimating spatial distribution of pollutant loads and its application in rural areas of Korea. J. Environ. Sci. 2015, 35, 1-11. [CrossRef] [PubMed]

30. Novotny, V. Water Quality: Diffuse Pollution and Watershed Management; John Wiley \& Sons: New York, NY, USA, 2003; ISBN 0-471-39633-8.

31. Sansalone, J.J.; Buchberger, S.G. Partitioning and First Flush of Metals in Urban Roadway Storm Water. J. Environ. Eng. 1997, 123, 134-143. [CrossRef] 
32. Vorreiter, L.; Hickey, C. Incidence of the first flush phenomenon in catchments of the Sydney region. In National Conference Publication-Institution of Engineers, Australia; Institution of Engineers: Sydney, Australia, 1994; pp. 359-364.

33. Ouyang, W.; Guo, B.; Hao, F.; Huang, H.; Li, J.; Gong, Y. Modeling urban storm rainfall runoff from diverse underlying surfaces and application for control design in Beijing. J. Environ. Manag. 2012, 113, 467-473. [CrossRef] [PubMed]

34. Soller, J.; Stephenson, J.; Olivieri, K.; Downing, J.; Olivieri, A.W. Evaluation of seasonal scale first flush pollutant loading and implications for urban runoff management. J. Environ. Manag. 2005, 76, 309-318. [CrossRef] [PubMed]

35. Kim, G.; Yur, J.; Kim, J. Diffuse pollution loading from urban stormwater runoff in Daejeon city, Korea. J. Environ. Manag. 2007, 85, 9-16. [CrossRef] [PubMed]

36. Schiff, K.; Tiefenthaler, L.; Bay, S.; Greenstein, D. Effects of Rainfall Intensity and Duration on the First Flush from Parking Lots. Water 2016, 8, 320. [CrossRef]

37. Dominik, L.; Dirk, M.; Mathias, U. Stormwater Pollutant Process Analysis with Long-Term Online Monitoring Data at Micro-Scale Sites. Water 2016, 8, 299. [CrossRef]

(C) 2017 by the authors. Licensee MDPI, Basel, Switzerland. This article is an open access article distributed under the terms and conditions of the Creative Commons Attribution (CC BY) license (http://creativecommons.org/licenses/by/4.0/). 